Eastern Illinois University

The Keep

Masters Theses

Student Theses \& Publications

$1-1-2013$

\title{
Don't waist your college experience: Administering nutrition education through Facebook
}

Brittany A. Zaring

Eastern Illinois University

This research is a product of the graduate program in Family and Consumer Sciences at Eastern Illinois

University. Find out more about the program.

\section{Recommended Citation}

Zaring, Brittany A., "Don't waist your college experience: Administering nutrition education through Facebook" (2013). Masters

Theses. 1230.

http://thekeep.eiu.edu/theses/1230

This Thesis is brought to you for free and open access by the Student Theses \& Publications at The Keep. It has been accepted for inclusion in Masters

Theses by an authorized administrator of The Keep. For more information, please contact tabruns@eiu.edu. 
*****US Copyright Notice ${ }^{* * * * *}$

No further reproduction or distribution of this copy is permitted by electronic transmission or any other means.

The user should review the copyright notice on the following scanned image(s) contained in the original work from which this electronic copy was made.

Section 108: United States Copyright Law

The copyright law of the United States [Title 17, United States Code] governs the making of photocopies or other reproductions of copyrighted materials.

Under certain conditions specified in the law, libraries and archives are authorized to furnish a photocopy or other reproduction. One of these specified conditions is that the reproduction is not to be used for any purpose other than private study, scholarship, or research. If a user makes a request for, or later uses, a photocopy or reproduction for purposes in excess of "fair use," that use may be liable for copyright infringement.

This institution reserves the right to refuse to accept a copying order if, in its judgment, fulfillment of the order would involve violation of copyright law. No further reproduction and distribution of this copy is permitted by transmission or any other means. 


\section{THESIS MAINTENANCE AND REPRODUCTION CERTIFICATE}

TO: Graduate Degree Candidates (who have written formal theses)

SUBJECT: Permission to Reproduce Theses

An important part of Booth Library at Eastern Illinois University's ongong mission is to preserve and provide access to works of scholarship. In order to further this goal, Booth Library makes all theses produced at Eastern Illinois University available for personal study, research, and other not-for-profit educational purposes. Under 17 U.S.C. § 108, the library may reproduce and distribute a copy without infringing on copyright; however, professional courtesy dictates that permission be requested from the author before doing so.

By signing this form:

- You confirm your authorship of the thesis.

- You retain the copyright and intellectual property rights associated with the original research, creative activity, and intellectual or artistic content of the thesis.

- You certify your compliance with federal copyright law (Title 17 of the U.S. Code) and your right to authorize reproduction and distribution of all copyrighted material included in your thesis.

- You grant Booth Library the non-exclusive, perpetual right to make copies of your thesis, freely and publicly available without restriction, by means of any current or successive technology, including but not limited to photocopying, microfilm, digitization, or internet.

- You acknowledge that by depositing your thesis with Booth Llbrary, your work is available for viewing by the public and may be borrowed through the library's circulation and interlibrary departmenst or accessed electronically.

- You waive the confidentiality provisions of the Family Educational Rights and Privacy Act (FERPA) (20 U.S.C. § 1232g; 34 CFR Part 99) with respect to the contents of the thesis, including your name and status as a student at Eastern Illinois Univerity.

\section{Petition to Delay:}

I respectfully petition that Booth Library delay maintenance and reproduction of my thesis until the date specified and for the reasons below. I understand that my degree will not be conferred until the thesis is available for maintenance and reproduction.

Date:

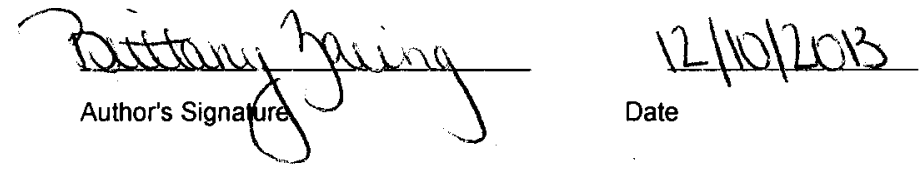

This form must be submitted in duplicate. 


\section{THESIS}

SUBMITTED IN PARTIAL FULFILLMENT OF THE REQUIREMENTS FOR THE DEGREE OF

Master of Sciences

IN THE GRADUATE SCHOOL, EASTERN ILLINOIS UNIVERSITY CHARLESTON, ILLINOIS

2013

YEAR

I HEREBY RECOMMEND THAT THIS THESIS BE ACCEPTED AS FULFILLING THIS PART OF THE GRADUATE DEGREE CITED ABOVE

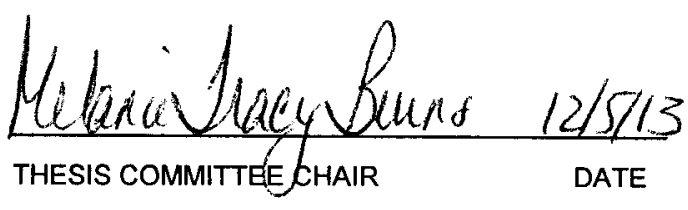

Richad wilkain 12/5/2013

THESIS COMMITTEE MEMBER

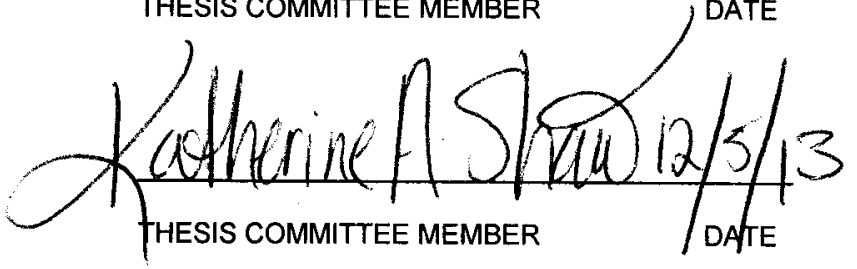

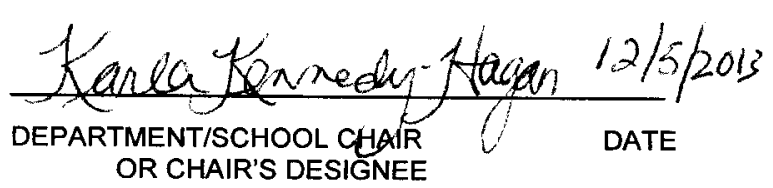

THESIS COMMITTEE MEMBER

DATE

THESIS COMMITTEE MEMBER 


\begin{abstract}
The purpose of this study was to evaluate the use of social media, specifically Facebook, as a medium of providing nutrition education and its impact on college students' food choices. A Facebook group was designed, Don't Waist Your College Experience, and college students were invited to join and participate in the nutrition education intervention and complete a pre- and post- revised version of the Rapid Eating Assessment for Patients (REAP). Fortytwo participants (98\% Caucasian, $86 \%$ females, $60 \%$ graduate students) completed the pre-REAP questionnaire and 10 of those also completed the post-REAP questionnaire. The questionnaire was designed to assess dietary and lifestyle habits. Descriptive statistics and a t-test were used to analyze the collected data. The results showed the participants were satisfied with the posted nutrition education; however, their engagement was limited making the nutrition education intervention ineffective. There was a significant change in the consumption of sodium $(p=0.00)$ and the sugar and added calories $(p=0.10)$. Online nutrition education offers the potential to improve dietary habits of college students.
\end{abstract}




\section{DEDICATION}

I dedicate this work to my husband, Paul. I could not have completed this effort without your continued love, encouragement, and sacrifice. I also like to dedicate this to my parents, David and Twylah. Throughout my childhood you taught me to never give up and pursue my dreams. This work was completed in part because of that persistence and perseverance you instilled in me. 


\section{ACKNOWLEDGEMENT}

I would like to acknowledge the following people for their contributions to this work:

Dr. Melanie Tracy Burns, my phenomenal thesis advisor, for her countless hours, unlimited guidance, and her unwavering support and encouragement. Her red pen compelled me to try harder and continue on. Her love and passion of teaching made me a better student. I will forever carry with me the lessons working with her on this process taught me.

Dr. Richard Wilkinson, my committee member, for his incredible understanding of research and statistics and the ability to help me understand it all.

Dr. Katie Shaw, my committee member, for her encouragement and cheery disposition. When I did not have faith to finish, her words and smile prompted me to carry on.

Meghan Leineweber, for her creativity and assistance that prevented my Facebook group from going nameless.

Lastly, I would like to acknowledge all of my wonderful friends that helped to recruit participants for my data collection: Rachael, Emily, and Becca. Without you this would have never been completed. 
TABLE OF CONTENTS

Abstract.

Page

Dedication

ii

Acknowledgements.....................................................................................

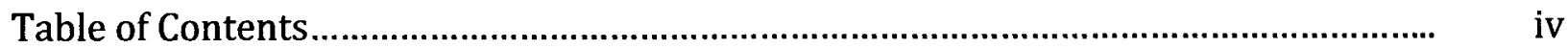

List of Tables and Figures............................................................................. vi

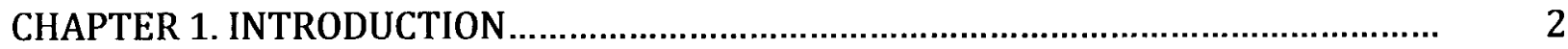

Statement of the Problem.............................................................................

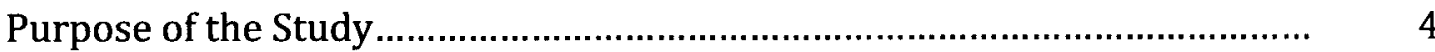

Significance of the Study ................................................................................... 4

Research Objectives.................................................................................. 4

Assumptions............................................................................................ 5

Operational Definitions........................................................................ 5

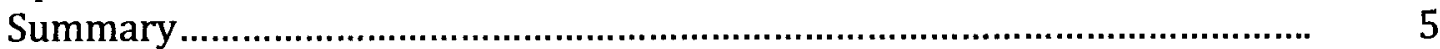

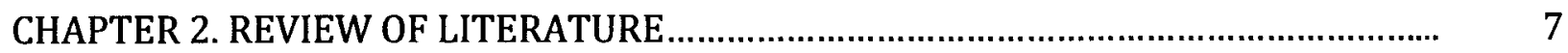

Dietary Guidelines............................................................................. $\quad 7$

College Student Diets................................................................................ $\quad 12$

Facilitating a Behavior Change in College Students.................................... $\quad 19$

Theory of Planned Behavior..................................................................... 19

Using Social Media for Behavior Change ................................................ $\quad 22$

Summary ................................................................................................. 26

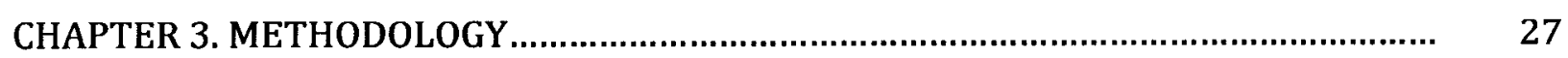

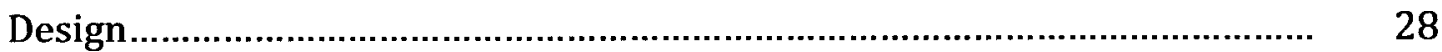

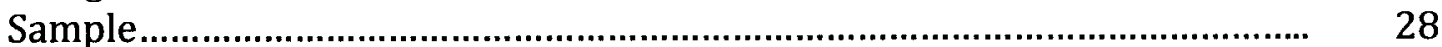

Instrumentation ............................................................................ $\quad 29$

Pilot Study ......................................................................................... $\quad 31$

Data Collection and Analysis................................................................... $\quad 31$

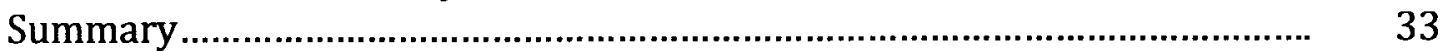


CHAPTER 4. RESULTS AND DISCUSSION.

Participant Demographics....................................................................... 34

Internal Consistency Reliability ................................................................ $\quad 35$

Objective 1 ................................................................................................. $\quad 36$

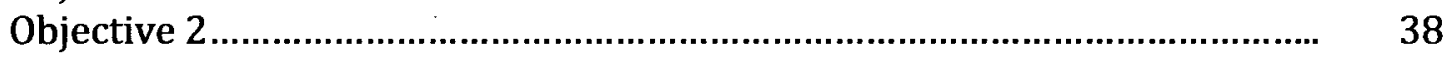

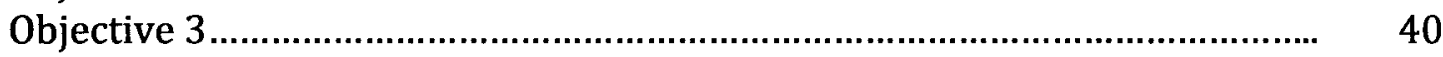

CHAPTER 5. SUMMARY, CONCLUSIONS, AND IMPLICATIONS.................................... 41

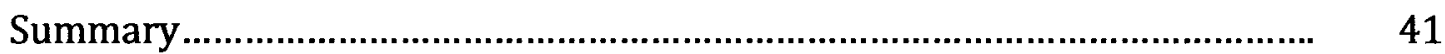

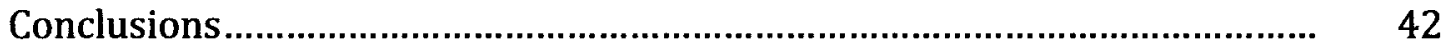

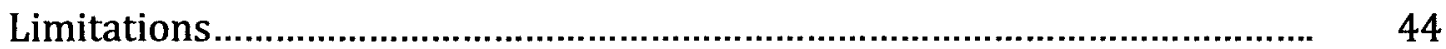

Implications and Recommendations..................................................... 45

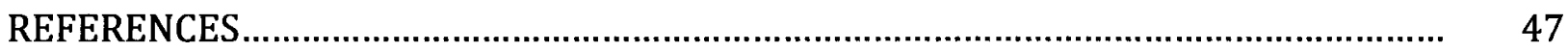

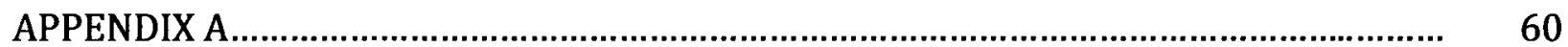

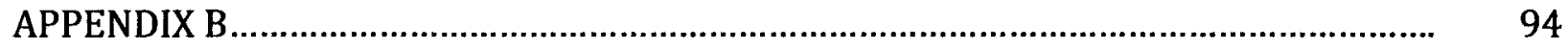

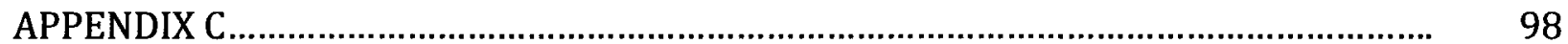




\section{LIST OF TABLES AND FIGURES}

Page

Table 1

Participant

Demographics.

Table 2

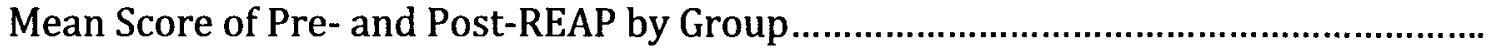

Table 3

Change in REAP Score by Participant and Mean..........................................................

Table 4

Change in REAP Score by Group............................................................................

Table 5

Mean Frequency of Perceived Effectiveness of Facebook Group 


\section{Chapter 1}

\section{Introduction}

\section{Statement of the Problem}

Every five years the United States Department of Agriculture (USDA) and the United States Department of Health and Human Services (DHHS) revise and update the Dietary Guidelines for Americans, with the most recent update released in 2010. As stated in the 2010 Dietary Guidelines for Americans, the key recommendations for Americans to maintain a healthy lifestyle include: balancing calories to maintain weight, reducing consumption of certain foods and increasing consumption of key foods and nutrients, such as whole grains, fruits and vegetables.

To assist Americans in achieving these dietary guidelines, the USDA released MyPlate (MyPlate, 2012). The MyPlate daily guidelines promote that the general population consume six servings of grains, half of which should be from whole grain; six servings of protein; four servings of fruit; five servings of vegetables; and three servings of dairy, with low-fat and non-fat options encouraged (MyPlate, 2012). A balanced and nutritious diet helps to provide all of the essential vitamins and minerals, which aids in decreasing the risk of cancer, obesity, heart disease, and diabetes (Martini, Cantania, \& Ferreira, 2010).

Recent research highlights that the typical college student does not adhere to these dietary guidelines (Jackson, Barry, \& Kennedy, 2011). While not quite the touted "Freshman Fifteen", college students typically gain, on average, three to seven pounds their first year on campus (Hoffman, Policastro, Quick, \& Lee, 2006; Mihalopoulous, Auinger, \& Klein, 2008), due, in part, to the consumption of more 
calories and fat than the recommended daily intake and less time engaging in physical activity (Edwards \& Meisleman, 2003). Common dietary practices of college students include skipping meals, drinking several carbonated and caffeinated beverages, and consuming high-calorie meals and snacks from fast food restaurants on a regular basis (Kolodinsky, et al., 2008; Louis, Davies, Smith, \& Terry, 2007).

To facilitate a behavior change in college students and promote healthier eating habits the Theory of Planned Behavior can be used. The Theory of Planned Behavior states that an individual's behavior is controlled by personal attitudes, social pressures, and his/her own control. The theory assumes that an individual makes a conscious decision to act and to make changes (Moss, 2008). This theory can be applied to facilitate a positive change in a college student's diet through influencing personal attitudes and intentions.

With more than half of Americans going online to seek medical information and advice as well as treatment options, social media is used to influence attitudes and intentions concerning healthy dietary choices (Kuehn, 2011). Currently, one in seven people in the world and one in four in the United States use Facebook (Bellis, 2013; Zeevi, 2013) with 67\% being female (Widrich, 2013). The typical Facebook user is between the ages of 18 and 28 (Widrich, 2013).

Various nutrition education groups use Facebook and can be found by conducting a search on the social media website. The Academy of Nutrition and Dietetics has several Facebook pages that provide members with news, updates, and 
resources related to the dietetics field (The Academy of Nutrition and Dietetics, 2013). The Journal of Nutrition Education and Behavior (JNEB) uses social media to reach and communicate current trends and educational materials to an audience that previously was inaccessible (Faust, 2010).

\section{Purpose of the Study}

The purpose of this study was to evaluate the use of social media, specifically Facebook, as a medium of providing nutrition education and its impact on college students' food choices.

\section{Significance of the Study}

Several studies have been conducted regarding the impact health education through social media has on different populations (Cousineau, Goldstein, \& Franko, 2004; Kicklighter, Koonce, Rosenbloom, \& Commander, 2010; LaChausse, 2012; Neuenschwander, Abbott, \& Mobley, 2013; Sakane et al., 2013). However, very little can be found regarding nutrition education through social media, specifically Facebook, to college students. This study will evaluate and examine the effectiveness of nutrition education administered through a social media medium by using a revised version of the Rapid Eating Assessment for Patients (REAP).

\section{Research Objectives}

The following objectives guided this study:

1. To determine if a significant difference exists between pre- and postintervention REAP scores. 
2. To determine if a significant difference exists between food group consumption pre and post intervention.

3. To determine the effectiveness of using Facebook as a medium to distribute nutrition education to college students.

\section{Assumptions}

Several assumptions were made throughout this study. The researcher assumed that participants would willingly, honestly, and actively participate in data collection and the Facebook nutrition education group, Don't Waist Your College Experience. Additionally, the researcher assumed that all participants were freeliving, full-time college students and eighteen years or older as identified through self-reported data.

\section{Operational Definitions}

For the purpose of this study, the following definitions were used. Malnutrition: A condition resulting from an energy or nutrient intake either above or below that which is optimal (Grosvenor \& Smolin, 2010) Social media: Forms of electronic communication, such as Web sites for social networking and micro-blogging, through which users create online communities to share information, ideas, personal messages, and other content, such as videos (Merriam-Webster, 2013)

\section{Summary}

During the college years, students tend to consume foods and engage in behaviors not in alliance with the 2010 Dietary Guidelines for Americans, thus 
impacting their weight status and overall health and well-being. This study examined the use of social media, specifically Facebook, as a medium to facilitate behavior change regarding healthy eating within a college population through the use of The Theory of Planned Behavior. 


\section{Chapter 2}

\section{Literature Review}

This section presents the literature relevant to improving the college student's diet. This review includes dietary guidelines and the current dietary recommendations for college students, the current average or typical diet of a college student, facilitating change in a college student, to use the Theory of Planned Behavior to facilitate behavior change, and the inclusion of social media to promote behavior change. Although there are various professional organizations dispersing nutrition education through the use of social media with college students turning to the internet for weight loss advice, little research has been conducted to evaluate and examine its effectiveness (LaChausse, 2012).

\section{Dietary Guidelines}

The Dietary Guidelines for Americans were first published in 1980 as a guide for Americans to utilize to make healthier choices regarding diet and physical activity (Dietary Guidelines for Americans, 2012). As mandated by the 1990 National Nutrition Monitoring and Related Research Act (Public Law 101-445), the United States Department of Agriculture (USDA) and the Department of Health and Human Services (DHHS) publish an updated version of the Dietary Guidelines for Americans every five years to reflect changes in nutrition science and to offer solutions to our ever-expanding obesity epidemic. These guidelines are edited to be unbiased, evidence-based, increased specificity and mildly challenging with the 
intent to impact and improve the current diet of Americans (Watts, Hager, Toner, \& Weber, 2011).

\section{Dietary Guidelines for Americans, 2010.}

The Dietary Guidelines for Americans, 2010 provides several recommendations and resources to the American population, both the general public as well as more specific populations, for a healthy lifestyle (Dietary Guidelines for Americans, 2012). Three main goals serve as the focal point of these recommendations, and include: (a) balance energy consumption with energy expenditure to maintain a healthy weight, (b) increase fruit, vegetable, whole grain, fat-free and low-fat dairy products, and seafood consumption, and (c) reduce sodium, saturated fat, trans fat, cholesterol, added sugars, and refined grain consumption (Dietary Guidelines for Americans, 2012).

To help American's manage a healthy lifestyle and achieve these goals the USDA released MyPlate in June 2011, which replaced MyPyramid (USDA, 2012). MyPlate daily guidelines for the general population provide guidelines for all food groups. The recommendation for grains for the general population is six one-ounce equivalent servings of grains (half of which should be whole grain) such as one slice whole wheat toast, one-half cup cooked rice, one-half cup cooked pasta, one-half bagel, and three cups popped popcorn. The recommendations for proteins for males of the general population are six one-ounce servings and five one-ounce servings for females with one ounce cooked meat, one egg, one tablespoon peanut butter, and one-fourth cup cooked beans representing a one ounce serving. The 
recommendation for fruit consumption for the general population is four one-cup equivalent servings with the following representing a serving of fruit: one cup applesauce, one medium pear, one cup pineapple, one cup $100 \%$ fruit juice, eight strawberries, and one-half cup dried fruit. The recommendations for vegetables for the general population is five one-cup equivalent servings; examples of a serving of vegetable are one cup chopped broccoli, two cups leafy greens, one cup $100 \%$ vegetable juice, one large baked sweet potato, and one large tomato. The recommendation for dairy for the general population is three one-cup equivalent servings, with low-fat and non-fat options encouraged; examples of a serving of dairy are one cup milk, two ounces cheese, two cups cottage cheese, one cup frozen yogurt, and one and half cups ice cream. The recommendation for oil for young adults of the general population is six teaspoons, one teaspoon margarine, one teaspoon mayonnaise, and one teaspoon vegetable oil representing a serving (MyPlate, 2012).

MyPlate provides a visual guide depicting half the plate with fruits and vegetable, the other half with grains and lean protein, and a serving of dairy at every meal. In addition, to eating a healthful, well-balanced diet the USDA recommends individuals exercise a total of 150 minutes a week to maintain proper body weight. If adults need to lose weight, the recommendation is that exercise be increased to 300 minutes a week (MyPlate, 2012).

By consuming a diet consisting of whole fruits and vegetables, whole grains, lean protein, and low-fat dairy products, the public is likely to increase intake of 
fiber, antioxidants and essential vitamins and minerals. Following a healthful diet helps in lowering the risks of cancer, diabetes, obesity, and heart disease.

Additionally, these essential vitamins and minerals found in these food choices play specific roles in various body processes to maintain homeostasis (Martini, Cantania, \& Ferreira, 2010).

A diet that is continually high in kcalories leads to weight gain and obesity. Weight gain is the precursor to elevated blood pressure, cholesterol, triglycerides, and blood glucose, and thus increasing the risk for heart disease and diabetes. Eating right and staying active combat these preventable diseases (Brown, 2011).

\section{Dietary Reference Intakes (DRIs).}

The Dietary Reference Intakes (DRIs) are a set of reference standards developed by the United States and Canada for the essential macro and micronutrients required by the human body (Mahan, Escott-Stump, and Raymond, 2012). The DRIs are divided into gender and age-specific categories to meet the needs of Americans throughout the lifespan. When following the guidelines depicted by MyPlate, the dietary reference intakes are most likely adequate.

The DRIs are broken down into Recommended Dietary Allowances (RDAs), Estimated Average Requirements (EAR), Adequate Intake (AI), and Upper Limit (UL). RDAs have been extensively researched and have been shown to meet the requirements of almost all of the healthy population. The EARs are the usual intake that is estimated to meet the requirements of half of the healthy population. The AIs lack scientific evidence and are based on experimentally derived intake levels to 
meet the needs of healthy individuals whereas the ULs are the levels set for the highest allowable dose before toxicity is reached (USDA NAL, 2013).

\section{Healthy People 2020.}

In addition to the Dietary Guidelines for Americans, 2010, the Healthy People goals are published every 10 years and include health objectives for communities as well as individuals. The most updated version, Healthy People 2020, was released in December 2010. The four overarching goals associated with Healthy People 2020:

(1) attain high-quality, longer lives free of preventable disease, disability, injury, and premature death, (2) achieve health equity, eliminate disparities, and improve the health of all groups, (3) create social and physical environments that promote good health for all, and (4) promote quality of life, healthy development, and healthy behaviors across all life stages (Healthy People, 2012, para 4).

This edition has 41 different topics and objectives (13 new) covering varying life stages, disease states, education, safety, and physical activity (Healthy People, 2012).

\section{Healthy Campus 2020.}

While Healthy People 2020 has objectives covering life stages for adolescents, early and middle childhood, maternal, infant, and child health, and older adults, college students specifically are not addressed. Thus, Healthy Campus 2020, an extension of the Healthy People 2020 goals, provides objectives specifically for college students as well as faculty and staff for achieving and maintaining a healthy 
body and lifestyle. Healthy Campus 2020 objectives were designed by the Task Force for National Health Objectives, taking a multi-disciplinary approach by requesting input from all American College Health Association (ACHA) regions of the United States. Similar to Healthy People, Healthy Campus is revised and updated every ten years (American College Health Association, 2012).

Healthy Campus 2020 has 11 topic areas and 54 objectives for students, with topics ranging from sleep to physical activity to family planning to nutrition and weight status. Nutrition and weight status objective includes (a) increase proportion of students at a healthy weight, (b) reduce proportion of students who are obese, and (c) increase proportion of students who report eating $\geq 5$ servings of fruits and vegetables per day. Physical activity and fitness objectives include (a) increase the proportion of students who report meeting federal guidelines for aerobic physical activity and (b) increase the proportion of students who report meeting federal guidelines for muscle-strengthening activity (American College Health Association, 2012).

\section{College Student Diets}

The USDA recommends that young adults 18 to 24 years of age consume six servings of grain (half whole grains) five to six ounces of protein, four servings of fruits, five servings of vegetables, three servings of dairy, and no more than six servings of oils. In addition to a healthful diet, guidelines recommend that young adults participate in 150 minutes of moderate-intensity exercise every week (MyPlate, 2012). 
Minerals of concern in this age group are zinc, calcium, and iron due to poor diet (Jamison, 1999). Zinc is essential in DNA and RNA synthesis, carbohydrate metabolism, and maintaining acid-base balance (Grosvenor \& Smolin, 2010). The DRI for zinc for males aged $19-30$ is $9.4 \mathrm{mg} /$ day and for females aged $19-30$ is 6.8 $\mathrm{mg} /$ day (USDA NAL, 2012). Calcium is essential in bone and teeth strength, muscle and nerve functioning, muscle contraction, blood pressure regulation, and blood clotting (Grosvenor \& Smolin, 2010). The DRI for calcium for males aged 19-30 is $800 \mathrm{mg} /$ day and for females aged 19-30 is $800 \mathrm{mg} /$ day (USDA NAL, 2012). Iron is a part of hemoglobin and myoglobin, which regulate the amount of oxygen traveling through the blood stream and the amount available in muscles (Grosvenor \& Smolin, 2010). The DRI for iron in males ages 19-30 is $6 \mathrm{mg} /$ day and for females aged 19-30 is $8.1 \mathrm{mg} /$ day (USDA NAL, 2012).

Vitamin $D$ is the vitamin of most concern in young adults due to a reduced intake of dairy products and oily fish (Barnes, Robson, Bonham, Strain, Wallace, 2006; Ganji, Milone, Cody, McCarty, Wang, 2010). Vitamin D helps to maintain adequate levels of calcium and phosphorus (Grosvenor \& Smolin, 2010). The DRI for vitamin D for males and females aged 19-30 is $10 \mu \mathrm{g} /$ day (USDA NAL, 2012).

\section{Current eating habits of college students.}

Previous research has shown that college students do not comply with the Dietary Guidelines for Americans (Adams \& Colner, 2008; Huang, Harris, Lee, Nazir, Born, \& Kaur, 2003). Calorie consumption of students on college campuses is increasing, while fruit and vegetable consumption remains the same since the 1990s 
(Adams \& Colner, 2008). One in four college students consume five or more fruits and vegetables a day, with young adults adopting more negative food behaviors as their food independence increases (Adams \& Colner, 2008; Huang, Harris, Lee, Nazir, Born, \& Kaur, 2003). In 1995, only $15 \%$ of college females consumed five or more servings of fruits and vegetables a day (Anding, Suminski, \& Boss, 2001). Today, fruit and vegetable consumption among college students has not increased (Adams \& Colner, 2008). Caucasian students attending a four year university consumed more fruits and vegetables than other ethnicities attending either a two year or four year program; however, they still did not meet the daily recommendations (Akan \& Grilo, 1995; Nelson, Larson, Barr-Anderson, NeumarkSztainer, \& Story, 2009).

Additionally, college students consume more fat and added sugars than the current recommendations. A survey was given concerning fast food consumption patterns related to college students $(n=132)$. Among these students, fast food consumption increased in the students who were less active, drank alcoholic beverages, and consumed caffeine (Jackson, Berry, \& Kennedy, 2009). A recent survey of 1,821 college students indicated that $47 \%(n=230)$ of male participants and $29 \%(n=386)$ of female participants were consuming on average more kcalories than required to maintain their body weight; a third of those kcalories from fat and 10\% came from saturated fat sources (Morrell, Logren, Burke, \& Reilly, 2011).

The consumption of sugar-sweetened beverages is higher in young adults than any other age group (Bleich, Wang, Wang, \& Gortmaker, 2008; Mullie, 
Aerenhouts, Clarys, 2012). An NHANES survey collected data from 1999-2004 compared the consumption of sugar-sweetened beverages by the following age groups 20-44 years old $(n=5713), 45-64$ years old $(n=2585)$, and $>65$ years old $(\mathrm{n}=3589) .72 \%$ of the participants in the $20-44$ regularly consumed sugarsweetened beverages, in contrast to $57 \%$ of the $45-64$ year old participants and $43 \%$ of the $>65$ year old participants (Bleich, et al., 2008). A survey of 50 participants aged 18-30 years old consumed more than half of their daily beverage calories from sugar-sweetened beverages. Male participants consumed a daily average of 2.2 cups and female participants consumed a daily average of 1.3 cups of sugar sweetened beverages ( 0 'Leary, Hattersley, King, \& Allman-Farinelli, 2012). Two-hundred and sixty five college students were surveyed about their sugarsweetened beverage consumption, $74 \%$ males and $61 \%$ females surveyed admitted to regularly consuming sugar-sweetened beverages with kcalorie consumption from these beverages being twice as high in African American students as Caucasian students (West, et al., 2012).

Weight gain in college is attributed to reduced physical activity and increased energy intake, in part to an elevated consumption of added sugars and fats. Current research has found that the average college student consumes more dietary fat than is recommended (Edwards \& Meisleman, 2003; Morrell, Logren, Burke, \& Reilly, 2011). Young adults and college students consume fewer than the daily recommended minimum five servings of fruits and vegetables (Lutfiyya, Chang, \& Lipsky, 2012; Murphy, Barrah, Herman, Cheatam, \& Randolph, 2012). They also do 
not consume the recommended daily servings of whole grains (Larson, NeumarkSztainer, Story, Burgess-Champoux, 2010). Eating a poor diet combined with reduced physical activity and sleep reduces the student's immune system and and lead to weight gain, diabetes, heart disease, and cancer (Grosvenor \& Smolin, 2010).

\section{Fabled “Freshman 15".}

When individuals enter college, gaining the "Freshman 15 " is often feared. After leaving home, students have a tendency to change several lifestyle habits, eating more convenience foods, exercising less, and consuming fewer fruits and vegetables, all of which can lead to weight gain in college (Smith-Jackson \& Reel, 2012). College freshman have a tendency to gain weight, typically, 3-7 pounds on average (Hoffman, et al., 2006; Mihalopoulos, Auinger, \& Klein, 2008). Male students gain more than their female counterparts gain with females experiencing greater dissatisfaction with body image (Simmons, Connell, Ulrich, Skinner, Balasubramanian, \& Gropper, 2011). Smith-Jackson and Reel (2012) postulate that female freshman fear weight gain in college and attribute the weight gain to food independence, body comparison to their peers, and influence from peers and family.

\section{Eastern Illinois University student consumption.}

Previous theses completed on Eastern Illinois University's (EIU) campus have focused on the eating and physical activity patterns of students attending EIU (Goetze, 2005; Ison, 2008; McCallister, 2008). In these studies, the researchers examined the current dietary habits of college students on Eastern Illinois University's campus. Ison (2008) explored students' reported knowledge of health 
benefits in consuming adequate fruits and vegetables, maintaining a healthy weight, and staying physically active. However, having this knowledge alone was not a motivator to follow current guidelines and recommendations. As identified by Goetze (2005) and later by Ison (2008), the average EIU student consumed inadequate servings of grains, fruits, and vegetable, and too many servings of meat. Additionally, college students reported not engaging in the recommended amounts of physical activity (McCallister, 2008).

Goetze (2005) used a survey to establish typical dietary patterns of college students $(n=492)$. The students' responses revealed a daily average consumption of 2-3 servings of grains, $0-1$ servings of vegetables, $2-3$ servings of fruit, $2-3$ servings of dairy, 2-3 servings of meat, and 2-3 servings of oils. All food groups were inadequately met by the students with the exception of meat (Goetze, 2005). Ison (2008) surveyed EIU students ( $\mathrm{n}=356$ ) to determine consumption of fruits and vegetables as well as motivators of and barriers to meeting the current recommendations. In 2008, EIU students consumed a daily average of 1.9 servings of fruit and 2.2 servings of vegetables. The top three health-related motivators to consuming fruits and vegetables were (a) contains vitamins, (b) has fewer calories, and (c) fights infections. Spoilage, lack of availability, and cost were all listed as barriers to meeting the daily recommendations. The results revealed that the barriers outweighed the motivators as fruit and vegetable consumption was inadequate (Ison, 2008). 
In 2008, McCallister developed, implemented, and evaluated a ten-week weight loss program entitled, "The Biggest Loser: You Gotta Low It to Win It" (McCallister, 2008). McCallister examined how participating in this nutrition education program could influence college students eating habits, physical activity levels, and subsequent weight loss. While 88 college students began the study, only $9 \%$ of the participants $(n=8)$ completed all phases of the program with a total weight loss of 27 pounds reported. The majority of the participants who withdrew from the program claimed to be too busy to continue with the program (McCallister, 2008).

\section{Body image concerns during the college years.}

While not examined specifically on EIU's campus, college females $(n=24,832)$ were more likely to be conscious of body size and diet and compared themselves to other females than did their male cohorts (Wharton, Adams, \& Hampl, 2008). Additionally, females often perceived themselves as weighing more than their actual weight. When asked, normal weight participants $(n=113)$ perceived a healthy weight to be $94 \%$ of their current weight, overweight participants $(n=35)$ perceived a healthy weight to be $85 \%$ of their current weight, and obese participants $(n=21)$ perceived $74 \%$ of their current weight (Malinauskas, Raedeke, Aeby, Smith, \& Dallas, 2006). A survey of 38,204 college students collected data regarding weight loss strategies and body weight perceptions. Twenty-eight percent of participants in this study were overweight or obese; however, one-third of those participants claimed to be overweight or obese. When the survey was issued, about three- 
fourths of participants were attempting to lose weight or maintain current weight, with the female cohorts to be significantly more likely to attempting weight loss or maintenance (Wharton, Adams, \& Hampl, 2008).

\section{Facilitating a Behavior Change in College Students}

Many college students today are exhausted, stressed, and overloaded. College students are tasked with balancing course load, a part- or full-time job, homework, family obligations, and, if lucky enough, a social life. Amidst all of these stressors, good nutrition is often times abandoned. While college students articulate concern for healthy food choices and the potential positive benefit to their lives, they frequently skip meals, drink several carbonated and caffeinated beverages, consume high- calorie snacks, and energy-dense fast food on a regular basis (Kolodinsky, et al., 2008; Louis, et al., 2007). Unhealthy food choices are selected due to the abundance of energy-dense convenience foods as compared ot the more nutrient dense options on the college campus as well as perceived lack of time to prepare healthy and nutritious meals (Ming-Chin, et al., 2010). Additionally, research has shown a positive relationship between unhealthy eating habits and stress, regardless of an individual's gender, weight, and social factors. The more an individual feels stressed, the more frequently unhealthy food choices are made by the individual (Cousineau, et al., 2004).

\section{Theory of Planned Behavior}

To assist college students in modifying these unhealthy behaviors, the Theory of Planned Behavior can be utilized when planning nutrition education 
interventions. The Theory of Planned Behavior, as developed by Ajzen and Fishbein, assumes an individual's actions are motivated by behavioral attitudes, subjective norms, and perceived behavioral control influencing intention, which leads to a behavior (Ajzen, 1985; Boyle \& Holben, 2013). The behavioral attitudes can be positive or negative; they reflect the cognitive beliefs and the affective assessments of an individual. The subjective norms are formed by the beliefs and motivation perceived as normal by society. Perceived behavioral control is the individual's perception of their ability to make a behavior change and their personal level of selfefficacy to make the change. If an individual's attitude is positive towards the change, perceives the change as a positive behavior, and conclude they have the knowledge and self-efficacy required, his/her intention will be to make a behavior change. Therefore, an individual's attitudes, self-efficacy, and intentions affect his/her ability to change a behavior.

To facilitate a behavior change in college students, the Theory of Planned Behavior will be used in this study. The Theory of Planned Behavior was developed by Icek Ajzen and Martin Fishbein and was used to study social influence and is often used in explaining health behavior (Ajzen, 1985). The Theory of Planned Behavior states that an individual's behavior is controlled by personal attitudes, subjective beliefs, and their control. This theory assumes that an individual makes a conscious decision to act and to make changes (Moss, 2008). And when an individual is self-motivated the likelihood of changing a specific behavior is increased (Jacobs, Hagger, Streukens, Bourdeaudhuij, \& Claes, 2011). As positive 
attitudes and previous behaviors have a direct impact on the intention to change a current behavior, nutrition education interventions can aid in an increasing an individual's level of self-efficacy and ability to change current attitudes and intentions (Goodwin \& Mullan, 2009).

\section{Application of the Theory of Planned Behavior to proposed study.}

As applied to this study, the Theory of Planned Behavior holds that the online nutrition education intervention will influence or explain the change in an individual's dietary patterns. This change can occur due to the increase in an individual's knowledge base, perceived behavioral control, and changed attitude toward healthy food decisions which can influence an individual's behavioral intention which can lead a behavior change (Moss, 2008). Increasing an individual's knowledge base by providing easy to prepare, quick recipes with nutritional information can influence the perceived behavioral control over choosing healthful food choices and ability to prepare. Influencing the knowledge and perceived behavioral control can lead to an improved attitude towards healthful eating patterns which can lead to a positive behavior intention leading an individual to make the intended behavior change. The online nutrition education included tips on how to prepare recipes and incorporate these meals into the college lifestyle, thereby increasing the participant's self-efficacy. Increased self-efficacy and perceived behavioral control can lead to a behavior change. 


\section{Using Social Media for Behavior Change}

As of 2011, Facebook had over 600 million users; approximately, 95 million users in the United States (Burbary, 2011). With one-third of the United States population regularly frequenting the same website, opportunity arises for influence to be made. Social media can target specific interest groups and has the potential to increase client/patient satisfaction, increase client/patient knowledge, and better self-management of diseases and conditions. Patients are also given the ability to provide feedback regarding the care they received (Masic, Sivic, Toromanovic, Borojevic, \& Pandza, 2012).

With the increased use of social media for health care there comes an increased risk to privacy and HIPPA violations, a potential diminished standard of care practices, and perceived and actual costs. Patients must consent to receive health care treatment through online sources and have their information sent across the internet (Hawn, 2009). In the 2010-2011 academic year, Penn State developed a mini-course called Friending Facebook? to educate health professionals on what social media is, what it can be, and how to use social media more effectively. The mini-course encouraged health professionals not to friend patients, but to create pages for different conditions and diseases to be used as a forum or support group. An additional promoted practice is for health professionals to friend their colleagues for ease in sharing medical advances, health and patient tips, and pertinent medical reports (George, 2011). Nutrition educators can apply these same practices to 
disseminate nutrition information to their patient/clients and/or to connect with other nutrition professionals.

Hello Health is a social media tool specifically designed for health professionals and their patients. Patients pay $\$ 35$ a month for membership, and are given the ability to send instant messages regarding the symptoms they are experiencing and receive medical advice. If the doctor needs more information, the patient and doctor can have a video chat for an additional nominal fee or the patient may receive an appointment for a consult in the doctor's physical office (Hawn, 2009).

As a quick Internet search will reveal, the internet offers weight loss tips, healthy cooking ideas, and physical activity routines for individuals of all ages. This advice can be free or the vendor may charge the consumer for them. Within the last ten years, numerous programs and websites specifically targeting college students for weight loss or promoting a healthy lifestyle have appeared online (Cousineau, et al., 2004). Today, an individual conducting an information search online for college weight loss programs can render over 61 million results. While online programs are not always the most trusted, some colleges and researchers have offered online courses, such as My Student Body-Nutrition, to college students to improve eating habits and physical activity. Results suggest that an effective online program focuses on healthy eating and not weight loss, food models and visuals, and an interactive component (Cousineau, et al., 2004; Kicklighter, Koonce, Rosenbloom, \& Commander, 2010; LaChausse, 2012). Additionally, Poddar, et al. investigated the 
opportunity to increase dairy consumption among college students through the use of an online course. After the eight-week intervention, those in the intervention group ( $n=97$ ) receiving the nutrition education increased their overall dairy consumption from less than three servings a day to three servings of dairy a day and increased self-regulation in choosing low-fat dairy options (Poddar, Hosig, Anderson-Bill, Nickols-Richardson, \& Duncan, 2012).

Research investigating the use of internet and web-based programs and nutrition education has been recently emerging. In Japan, a 12 week intervention program on increasing physical activity and healthy eating habits was administered through a web-based program alone and a combined program of web and visceral fat measurement group. Both groups lost an average of four to six pounds and saw a reduction in waist circumference (Sakane et al., 2013).

Various federal food assistance programs have documented successes with online nutrition education interventions. In Indiana, a web-based program was used to provide nutrition education to those within the Supplemental Nutrition Assistance Program Education (SNAP-Ed) due to budget cuts. Results of the webbased education were similar to that of nutrition education received in-person (Neuenschwander, et al., 2013). The Special Supplemental Nutrition Program for Women, Infant, and Children (WIC) also utilizes the internet to access clients and provide them with nutrition education necessary to receive food vouchers. Due to the inability of some participants to make appointments regularly, online courses 
were offered. The option of online nutrition education increased the effectiveness of the nutrition education and of the supplementation program (Teng, et al., 2009).

Various nutrition education groups use Facebook and can be found by conducting a search on the social media website. The education groups can be used as forums for those with the issue or disease or as a way to disseminate health tips on controlling or treating their disease state, such as diabetes, cancer, or weight loss. There are Facebook pages for exercise and fitness programs as well as commercial weight loss programs, such as, Jenny Craig, Nutrisystem, and Weight Watchers (Health, Fitness and Beauty Secrets, 2013; Jenny Craig, 2013; Nutrisystem, 2013; Weight Loss, 2013; Weight Watchers, 2013).

More credible professional organizations also can be found on Facebook. The Academy of Nutrition and Dietetics offers many Facebook pages for their members to be provided with news, updates, and various resources related to the various aspects of the dietetics field (The Academy of Nutrition and Dietetics, 2013). Kristin Faust, managing editor of Journal of Nutrition Education and Behavior (JNEB), uses both Facebook and Twitter to discuss weekly highlights of the journal. JNEB uses social media to reach out to the readers to communicate current trends and educational materials and to an audience that has previous been inaccessible (Faust, 2010). The USDA has been using Facebook since 2011 to post nutrition tips and health recipes through their MyPlate page. It aims at providing information regarding the key areas from the 2010 Dietary Guidelines (Academy of Nutrition and Dietetics, 2013). 


\section{Summary}

Diet directly affects the health of individuals. With college students not consuming the daily recommended intake of many vitamins and minerals as well as the recommended intake from the food groups as depicted on MyPlate. These choices, thereby increase their risk of obesity and chronic diseases, such as heart disease, diabetes, and cancer.

Social media has allowed for several advances in health care including how health information reaches consumers. One can infer that these online education efforts can be replicated for nutrition education. By providing online nutrition education, behavior changes can be promoted within populations who frequently utilize social media, e.g. college students. Effective online nutrition education interventions must focus on healthy eating habits, include food visuals, and have an interactive component for the users. The next chapter will describe and explain the research design and methodology used in this study aimed at improving the average college student's diet through the use of social media. 


\section{Chapter 3}

\section{Methodology}

The purpose of the study was to evaluate the use of social media, specifically Facebook, as a medium of providing nutrition education and its impact on college students' food choices. Sixty-seven percent of internet-users worldwide use Facebook. The typical Facebook user is $18-29$ years old and is in college or has graduated from college. The majority of Facebook users are female, 55\% of the Facebook users in the United States are female and $67 \%$ of the worldwide users are female (Widrich, 2013). The researcher designed and used a Facebook group, Don't Waist Your College Experience, as the social medium to disseminate healthy menu ideas and tips that adhere to the Dietary Guidelines for Americans, 2010.

The Facebook group was available for three weeks to 'friended' college students. According to Maltz (1989), behavior changes take an average of 21 days to occur. Maltz's assumptions has caused several website bloggers and authors to write on the topic of forming new habits and behavior changes in 21 days. Each week had a separate theme: healthy dinners, food on the go compared to its fast food counterpart, and breakfast. Daily recipes, including nutritional information, were posted in addition to specific health-related nutrition information (Appendix A). Participants were asked to complete a food frequency questionnaire, a revised version of the Rapid Eating Assessment for Patients (REAP) before and after (Appendices B and C, respectively) the 21 day nutrition education series. Three research objectives guided this study: 
1. To determine if a significant difference exists between pre- and postintervention REAP scores.

2. To determine if a significant difference exists between food group consumption pre and post intervention.

3. To determine the effectiveness of using Facebook as a medium to distribute nutrition education to college students.

\section{Design}

Quantitative data were collected through a food frequency questionnaire and questions designed to evaluate the viability of using Facebook as a medium for nutrition education.

Recipes posted on Don't Waist Your College Experience were found at allrecipes.com (AllRecipes, 2013), epicurious.com (Epicurious, 2013), or were the researchers own creations. Fast food nutrition information was found at company's respective websites, mcdonalds.com (McDonald's, 2013), pizzahut.com (Pizza Hut, 2013), jimmyjohns.com (Jimmy John's Gourmet Sandwiches, 2013), arbys.com (Arby's, 2013), and tacobell.com (Taco Bell, 2013). Nutritive analyses of the recipes were completed using NutritionData (NutritionData.com, 2013). A slightly modified version of the REAP questionnaire (Miller, 2005) posted on Qualtrics (Qualtrics Labs Inc., Provo, UT) was used for this study.

\section{Sample}

Participants were recruited through the use of flyers posted at the host Midwestern state university. Invited individuals included undergraduate and 
graduate students enrolled in college full-time. Five gift cards from Starbucks and Wal-Mart worth $\$ 25$ each were randomly provided as incentives for participants to complete the entire study including the pre- and post- REAP questionnaire and online nutrition education. The Don't Waist Your College Experience Facebook group was opened one week prior to the study start date to allow Facebook users to join the group and to complete the online survey with additional participants recruited through the snowball sampling technique (Byrnes, 2011). The researcher encouraged participants to invite their Facebook friends who were attending other colleges. Participants, both male and female, were approximately 18 to 25 years old and the ethnicities of the participants varied on those who joined the Facebook group. Participants were excluded if they were not currently enrolled full-time in a university program, or if they chose not to complete the assessment prior to the study start date. Permission to conduct this study was obtained from Eastern Illinois University Institutional Review Board (IRB number 13-122).

\section{Instrumentation}

Members of the Don't Waist Your College Experience Facebook group were asked to complete a modified version of the Rapid Eating Assessment for Patients (REAP) before and after the three-week nutrition education intervention. The REAP tool, which was designed to determine a patient's risk for malnourishment, was validated for use in the medical setting (Gans, et al., 2003). The REAP assesses food consumption and eating habits (Miller, 2005). The original REAP has excellent reliability $(\mathrm{r}=0.86)$ and been shown to have high validity when pilot tested among 
physicians and medical students. The revised version REAP was calculated to have a reliability score of 0.969 . REAP reflects all food groups and their respective serving sizes. The original assessment was comprised of 31 total questions for the participant, 27 food frequency questions, three food behavior risk questions, and one question for readiness of behavior change using the Likert scale. A response of "usually/often" for questions 1-27 indicates an at-risk nutrition habit. A response of "no" for question 28 or "yes" for questions 29-30 indicates an at-risk food behavior. When a patient answers five or more questions that indicates an at-risk nutrition habit, a patient is to be referred to a registered dietitian (Gans, et al., 2003; Miller, 2005). For use in this study, the researcher modified the REAP survey through the addition of 11 questions to the pre-test: a question to assess refined grain intake, five questions to further assess fruit variety consumption, as well as five questions to further assess vegetable variety consumption as depicted in the USDA MyPlate guidelines (MyPlate, 2013). Additionally, the assessment collected demographic and personal information as well as food habits consumption data. The purpose of the modified REAP survey was to obtain eating habits of college students and to assess if the three-week nutrition education intervention administered through social media was effective as determined by an score difference on the REAP assessment . Four questions were added to the post-test to gather quantitative data from participants to assess the level of effectiveness of the online nutrition education. The survey took participants five to seven minutes to complete. 
Face validity regarding the instrument's ability to assess the participant's usual dietary intake was sought from an expert panel of three local dietitians as well as the researcher's thesis committee (Bornstein, 2013). Internal Consistency Reliability was tested after data was collected by conducting the split-halves test. Questions 1-41 were split in half by using the even-odd approach and each half was scored. The reliability coefficient was calculated from the two scores (Oregon Department of Education, 2010).

\section{Pilot Study}

A pilot study was conducted for this research in February 2013 using Qualtrics $®$. The pilot study examined the components of the REAP questionnaire and the data collection mechanism. The survey was piloted with eight students (75\% female, $63 \%$ undergraduate) enrolled at the same Midwestern university. The survey took the students between five and seven minutes to complete. Based on comments and concerns of those who completed the survey, adjustments were made for clarification as well as the addition of the questions related to MyPlate addressed earlier.

\section{Data Collection and Analysis}

Upon accessing the modified REAP questionnaire, participants were asked to create a code using the first two letters of their first name, first three letters of the month in which they were born, year they graduated high school, and first letter of their eye color. The researcher used the codes to identify pre- and post-assessment responses. Data collected from the pre- and post-assessment was evaluated for 
differences in the consumption of different food groups and in individual questions shown by an increase or decrease in the composite score. If a difference was established, the researcher examined the data for relationships among the participants' age, gender, ethnicity, and grade level.

The REAP assessment (appendices B and C) was scored by an answer of "usually/often" for questions 1-41 received three points, an answer of "sometimes" for questions 1-41 received two points, and an answer of "never" for questions 1-41 received one point. The higher a participant scored on his/her REAP assessment, the greater the risk of undesirable habits. The maximum score possible was 123 points.

Nutrition and food composition data was analyzed for differences between dietary changes pre and post intervention Microsoft $₫$ Office Excel 2010 and SPSS $®$ 20.0 (IBM® Armonk, NY). The effectiveness of using Facebook as a medium to distribute nutrition education to college students was determined through frequency distribution.

Changes in participants' dietary intake were entered in Microsoft ${ }^{\circledR}$ Office Excel 2010. Independent samples t-tests using SPSS $₫ 20.0$ (IBM@ Armonk, NY) were conducted to determine if there was a significant difference in the overall dietary consumption pre- and post-REAP questionnaire and to determine if there was a significant difference in food group consumption pre- and post-REAP questionnaire with a pre-determined significance level of $p \leq .10$ due to the small sample size (CancerGuide, 2001). Answers given for questions $43-46$ on post-test 
were evaluated by the researcher using descriptive analysis to determine the level of effectiveness of the nutrition education provided through the Facebook group, Don't Waist Your College Experience.

\section{Summary}

A Facebook group, Don't Waist Your College Experience, was developed as a nutrition education intervention to provide students attending a four-year university with healthy recipes for dinner, on-the-go meals, and breakfast along with their nutritive value and price per portion for three weeks. Participants in the Facebook group were asked to complete the modified REAP questionnaire before and after participation in the online group to determine the effectiveness of the online intervention administered via Facebook. Independent samples t-tests were conducted using SPSS $\circledast 20.0$ to determine if there is a significant difference in the overall dietary consumption and in the individual food group consumption pre- and post-REAP questionnaire with a pre-determined significance level of $p \leq .10$ due to small sample size. 


\section{Chapter 4}

\section{Results and Discussion}

The purpose of this study was to evaluate the use of social media, specifically Facebook, as a medium of providing nutrition education and its impact on college students' food choices. The study used a revised Rapid Eating Assessment for Patients to evaluate the dietary intake before and after the nutrition education intervention. The questionnaire consisted of 41 multiple choice questions that assessed the participant's intake of grains, fruit, vegetables, dairy, protein, fat, sweets and added calories, sodium, and lifestyle. Three objectives guided this study:

1. To determine if a significant difference exists between pre- and postintervention REAP scores.

2. To determine if a significant difference exists between food group consumption pre and post intervention.

3. To determine the effectiveness of using Facebook as a medium to distribute nutrition education to college students.

\section{Participant Demographics}

Demographic data are represented in Table 1. Invitations were sent to the researcher's college Facebook friends to join the page Don't Waist Your College Experience, and through snowball sampling, other college Facebook members were invited. The page received 99 likes and 42 of the page members completed the preREAP questionnaire. The majority of participants were Caucasian (98\%) females (86\%) attending graduate school (60\%). The mean age of participant was $25 \pm 6.85$. 
Table 1

\begin{tabular}{lll} 
Participant Demographics $(n=42)$ & & \\
\hline Characteristic & $\mathrm{N}$ & $\%$ \\
\hline Gender & 6 & 14.3 \\
Male & 36 & 85.7 \\
Female & & \\
Ethnicity & 0 & 0.0 \\
Hispanic or Latino & 0 & 0.0 \\
American Indian or Alaska Native & 1 & 2.4 \\
African American & 0 & 0.0 \\
Native Hawaiian or Other Pacific Islander & 41 & 97.6 \\
White and Caucasian & & \\
Grade Level* & 0 & 0.0 \\
Freshman & 7 & 16.7 \\
Sophomore & 3 & 7.1 \\
Junior & 6 & 14.3 \\
Senior & 25 & 59.5 \\
Graduate & & \\
Student Status & 34 & 81.0 \\
Full-time & 8 & 19.0 \\
Part-time & & \\
\hline
\end{tabular}

\section{Internal Consistency Reliability}

The reliability of the revised REAP questionnaire was determined using the internal consistency reliability split-halves test. Questions 1-41 were divided in half by using the even-odd approach and each half was scored. Internal reliability from the two scores was calculated using Microsoft® Office Excel 2010. Test determined $r=0.969$, indicating a strong relationship scores (Oregon Department of Education, 2010). 
Objective 1. To Determine if a Significant Difference Exists between Pre- and Post-intervention REAP Scores

Table 2 illustrates the difference in the pre- and post-REAP mean scores by each food group by all participants. Tables 3 illustrates the difference in the preand post-REAP scores by each participant and mean score of all participants. Participants received three points for every "usually/often" response, two points for every "sometimes" response, and one point for every "never" response. The results show there was no significant difference in the overall change in score of the preand post-REAP questionnaires.

These findings were inconsistent with similar studies using social media to initiate a behavior change. Previous studies found that after an 8 to 12 week webbased nutrition education interventions improved healthy dietary consumption, weight loss, and reduced waist circumference (Poddar, et al., 2012; Sakane et al., 2013).

Time and exposure to the nutrition education intervention were limiting factors to the success of this study. This current study lasted 21 days, which lasted approximately $25 \%$ as long as previous effective online nutrition education interventions. Increasing the time and information provided could have yielded different results. 
Table 2

Mean Score of Pre-and Post-REAP by Group

\begin{tabular}{lccc}
\hline & $\begin{array}{c}\text { Pre-REAP } \\
\text { Score }\end{array}$ & $\begin{array}{c}\text { Post-REAP } \\
\text { Score }\end{array}$ & Difference \\
\hline Grain & 4.9 & 4.8 & 0.1 \\
Fruit & 12.1 & 11.3 & 0.8 \\
Vegetable & 11.9 & 10.6 & 1.3 \\
Dairy & 4.8 & 5.1 & $<0.3>$ \\
Protein & 8.7 & 8.5 & 0.2 \\
Fat & 8.6 & 8.3 & 0.3 \\
Sweets and Added Calories & 6.4 & 7.8 & $<1.4>$ \\
Sodium & 2.4 & 6.9 & $<4.5>$ \\
Lifestyle & 13.0 & 12.0 & 1.0 \\
Total & 74.8 & 75.0 & $<0.2>$ \\
\hline
\end{tabular}

Table 3

Change in REAP Score by Participant and Mean

\begin{tabular}{cccc}
\hline Participant & Pre-Reap Score & Post-Reap Score & Difference \\
\hline 1 & 65 & 56 & 9 \\
2 & 75 & 71 & 4 \\
3 & 74 & 70 & 4 \\
4 & 89 & 105 & $<16>$ \\
5 & 74 & 71 & 3 \\
6 & 79 & 82 & $<3>$ \\
7 & 69 & 63 & 6 \\
8 & 64 & 69 & $<6>$ \\
9 & 84 & 78 & 6 \\
10 & 75 & 85 & $<10>$ \\
Mean* & 74.8 & 75 & $<0.2>$
\end{tabular}

${ }^{*} \mathrm{p}=0.939$ 


\section{Objective 2. To Determine if a Significant Difference Exists between Food Group Consumption Pre and Post Intervention}

Table 4 illustrates the difference in the pre and post REAP scores of the eight assigned food groups and lifestyle factors. There was no significant change in the grain, fruit, vegetable, dairy, protein, and fat food groups. There was no significant change in the lifestyle factors. The results show there was a significant $(\mathrm{p}<.10)$ change in the consumption of sugar and added calories and sodium.

The Dietary Guidelines for Americans 2010 recommends for the general population six one-ounce equivalent servings of grains, five to six ounces of protein, four cups of fruit, five cups of vegetables, and three cups of dairy (MyPlate, 2012). One of the main objectives for Healthy Campus 2020 is to increase the proportion of students who report eating $\geq 5$ one-cup servings of fruits and vegetables a day (American College Health Association, 2012). The participants' mean pre-REAP score for grain-related questions was 4.0 and the post-REAP score was 3.5 ; this indicated an typical answer of "sometimes" to consuming the recommended intake of grains. The participants' mean pre-REAP score for fruit- related questions was 12.2 and post-REAP score was 12.7; this indicated an typical answer of "sometimes" to consuming the recommended intake of fruits. The participants' mean pre-REAP score for vegetable-related questions was 11.3 and post-REAP score was 12.1 ; this indicated an typical answer of "sometimes" to consuming the recommended intake of vegetables. This is consistent with current research. College students do not meet the daily recommendations for whole grains, fruits, and vegetables (Adams \& 
Colner, 2008; Akan \& Grilo, 1995; Anding, Suminski, \& Boss, 2011; Goetze, 2005;

Huang, Harris, Lee, Nazir, Born, \& Kaur, 2003; Ison, 2008; Nelson, Larson, Barr-

Anderson, Neumark-Sztainer, \& Story, 2009). Questions related to protein and dairy on the REAP questionnaire focused on types selected and not on quantity.

Current research shows higher intake of fat and added sugars are higher in the college population (Bleich, Wang, Wang, \& Gortmaker, 2008; Jackson, Berry, \& Kennedy, 2009; Morrell, Logren, Burke, \& Reily, 2011; Mullie, Aerenhouts, Clarys, 2012). Participants in this study significantly increased their intake of sodium and fats and added sugars. This finding is inconsistent with research that focuses on healthy eating and not weight loss (Cousineau, et al., 2004; Kicklighter, Koonce, Rosenbloom, \& Commander, 2010; LaChausse, 2012).

Table 4

Change in REAP Score by Group

\begin{tabular}{lccc}
\hline Group & Mean Difference & Standard Deviation & $\mathrm{t}$ \\
\hline Grain & .100 & .568 & .557 \\
Fruit & .800 & 2.860 & .885 \\
Vegetables & 1.300 & 2.312 & 1.778 \\
Dairy & -.300 & 1.418 & .669 \\
Protein & .200 & 1.033 & .612 \\
Fat & .300 & 1.947 & .487 \\
Sweets and Added & -1.400 & 2.413 & -1.835 \\
Calories* & & & \\
Sodium** & -4.500 & 1.716 & -8.293 \\
Lifestyle & 1.000 & 2.160 & 1.464 \\
\hline
\end{tabular}

${ }^{*} \mathrm{p}=0.100$

${ }^{* *} \mathrm{p}=0.000$ 
Objective 3. To Determine the Effectiveness of using Facebook as a Social Medium to Distribute Nutrition Education to College Students

Table 5 illustrates the mean frequency of the perceived effectiveness of the Facebook group, Don't Waist Your College Experience. Twenty-four percent of participants $(n=10)$ completed the nutrition education intervention and the postREAP questionnaire. Similar participant engagement and retention has been seen in another nutrition education intervention done at Eastern Illinois University (McCallister, 2008).

Half of the students checked the Facebook page 1-3 times weekly and were mostly satisfied with the nutrition education provided (mean score of 3.56). The majority of participants $(70 \%)$ indicated they found the information posted to be moderately useful and would be moderately willing to share the information posted on the Facebook page with others.

Table 5 .

Mean Frequency of Perceived Effectiveness of Facebook Group

\begin{tabular}{lccc}
\hline & $\mathrm{n}$ & Mean Frequency & Interpretation \\
\hline Frequency $^{1}$ & 10 & 3.700 & Checked 2-3x/week \\
Satisfaction $^{2}$ & 9 & 3.556 & Moderately Satisfied \\
Usefulness $^{3}$ & 9 & 2.00 & Moderately Useful \\
Willingness $^{4}$ & 9 & 4.111 & Moderately Willing \\
\hline
\end{tabular}

${ }^{1}$ Response to question: How frequently did you check the Facebook group, Don't Waist Your College Experience?

${ }^{2}$ Response to question: On a scale from 1 to 5,1 being not at all and 5 being very satisfied, how satisfied were you with your experience with the Facebook group, Don't Waist Your College Experience?

${ }^{3}$ Response to question: How useful did you find the information posted on the Facebook group, Don't Waist Your College Experience?

${ }^{4}$ Response to question: On a scale from 1 to 5,1 being not at all and 5 being very willing, how willing are you to share this information with others? 


\section{Chapter 5}

\section{Summary, Conclusions, and Implications}

\section{Summary}

The purpose of this study was to evaluate the use of social media, specifically Facebook, as a medium of providing nutrition education and its impact on college students' food choices. The Theory of Planned Behavior was applied to promote a behavior change in college students and their dietary choices. College students' dietary intakes before and after a three-week nutrition education intervention posted on a created Facebook page called Don't Waist Your College Experience. Participants were asked to complete a revised Rapid Eating Assessment for Patients (REAP) questionnaire before the intervention began. One recipe and a nutrition tip were posted onto the Facebook page every morning during the three-week intervention. After the intervention, participants were asked to complete the REAP questionnaire again.

The REAP questionnaire contained 42 questions regarding the participants' grain, fruit, vegetable, dairy, protein, fat, sweets and added calories, and sodium intake and their lifestyle. The post-REAP questionnaire contained 4 added questions regarding the participants' perceived effectiveness of the nutrition education intervention. Forty-two participants completed the pre-REAP questionnaire, of which 10 completed the post-REAP questionnaire. There was no significant change in the overall dietary choices made by college students in the three week period. However, a significant difference was noted in the sodium 
$(\mathrm{p}=0.00)$ and the sugars and added calories $(\mathrm{p}=0.10)$ sections. While students were satisfied with the nutrition education posted on the Facebook page, their engagement with the information was limited. These results imply this nutrition education intervention was ineffective at initiating a behavior change in college students to improve dietary behavior. Future online interventions need to provide an interactive component that allows the participants to become actively engaged in the intervention.

\section{Conclusions}

Results of this study indicate the nutrition education intervention was ineffective. The nutrition education intervention failed to make a behavior change in the college student dietary choices. Participants were not actively engaged in the Facebook group suggested Facebook was not an effective medium to distribute nutrition education.

Objective 1. To determine if a significant difference exists between preand post- intervention REAP scores.

The results of the study indicated the online nutrition education provided through a Facebook group called Don't Waist Your College Experience was ineffective. There was no significant change in the overall dietary choices made by college students in the three week period. The mean score calculated for the ten participants that completed the pre-REAP and the post-REAP questionnaires were 74.80 and 75.00 , respectively. This implies there was no difference in dietary habits after the nutrition education intervention was provided. The change in pre- and 
post- REAP scores is minute and it can be assumed very little to no change occurred in the participant's overall dietary habits. The participant's reflection on their dietary intake could have been slightly different from the time of completion for the pre-REAP questionnaire to the time of completion of the post-REAP questionnaire.

Objective 2. To determine if a significant difference exists between food group consumption pre- and post-intervention.

The questionnaire was divided into nine categories: grains, fruit, vegetables, dairy, protein, fat, sweets and added calories, sodium, and lifestyle. Slight improvement was shown in the grains, fruit, vegetables, protein, fat, and lifestyle choices made by the ten participants who completed the pre-REAP and the postREAP questionnaire. The participant's mean scores for dairy, sweets and added calories, and sodium revealed poorer choices were made after the intervention. Two of the categories, sweets and added calories and sodium, showed a significant $(p<.10)$ change in the pre-REAP and post-REAP mean scores. These results imply the nutrition education intervention was ineffective at initiating a behavior change in college students to improve dietary behavior.

objective 3. To determine the effectiveness of using Facebook as a social medium to distribute nutrition education to college students. The Facebook group, Don't Waist Your College Experience, received 99 “likes". Of those 99, 42 members completed the pre-REAP questionnaire with 10 completing the post-REAP questionnaire. While those 10 who completed the postREAP were satisfied with the information posted online and found it to be useful 
there was limited exposure to the page. The page was designed for followers to check the page daily; the majority of participants indicated they checked the page a few times a week. This indicated minimal engagement from the participants which could explain the regression in dietary choices made by the participants in the study.

\section{Limitations}

Limitations identified throughout this research study include: a small convenience sample of nutrition-minded individuals, the inability to follow-up with participants due to the anonymity of the participants, and daily posts not appearing in participant's Facebook "feed". This study used a convenience sample of 10 college students between 18 and 48 years old with the majority of participants recruited through the researcher's Facebook friends list and the Eastern Illinois University Student Dietetic Association Facebook page. Consequently, these findings were limited due to the participants sharing similar characteristics and nutrition knowledge.

The majority of participants that completed the post-REAP questionnaire were undergraduate and graduate dietetic students. These participant's scores indicated they made healthful choices the majority of the time and allowed for little improvement after the nutrition education intervention.

The anonymity of the participants limited the researcher in being able to follow-up with participants to encourage to take the post-REAP questionnaire or to 
inquire about the constraints that kept participants from checking the page daily and being actively involved.

A final limitation of the study was a "glitch" in the Facebook page not appearing daily within the participants newsfeed. This was reported by several of the researcher's Facebook friends at various times throughout the intervention and was outside of the researcher's control. The page was intended for members to receive recipes and nutrition education daily. As a result, if members of the group did not intentionally check the Facebook page, Don't Waist Your College Experience, daily no education was provided thereby hindering the effectiveness of facilitating the desired behavior change.

\section{Implications and Recommendations}

Based on the results of this study, dietary and lifestyle modification programs and nutrition education are still necessary within the college population. There was limited response received from this study. However, college students frequently use social media to acquire and research information and connect and share with friends and family. Social media can be used as an effective tool to facilitate behavior change in college students and to disseminate nutrition information. Three weeks is an inadequate amount of time to provide a nutrition education intervention and to reflect a change in dietary behavior in the college population.

If this study is to be replicated, the promotion of the Facebook group should be advertised on multiple campuses a minimum of two weeks prior to the start date 
and an ad should be placed in various campus papers advertising the page allowing students adequate time to join and invite friends to participate. Though research shows a behavior change can occur in 21 days (Maltz, 1989), this study should follow that of previous effective online nutrition education interventions and continue for a minimum of eight weeks as it may take longer to initiate a diet behavior change (Poddar, Hosig, Anderson-Bill, Nickols-Richardson, \& Duncan, 2012). This would provide adequate time for participants to become engaged and make changes suggested in the nutrition education intervention. Information that is posted should be easy to understand and interactive encouraging engagement from participants. Health Services on the college campuses involved in group could facilitate an education program to be initiated in tandem with the online education piece creating an accountability piece to the study. Recipes and the nutrition education pieces that have been posted online could be distributed throughout college campuses. Data could also be collected concerning the participant's college location and participant contact information. Further research is needed to continue exploring the opportunities of social media to influence college student's dietary behaviors. 


\section{References}

Academy of Nutrition and Dietetics. (2013). MyPlate is now reaching more consumers through social media. Journal of the Academy of Nutrition and Dietetics, 113(6), 754-755.

Adams, T. \& Colner, W. (2008). The association of multiple risk factors with fruit and vegetable intake among nationwide sample of college students. Journal of American College Health, 56(4), 455-461.

Ajzen, I. (1985). From intentions to actions: A Theory of Planned Behavior. SSSP Springer Series in Social Psychology, 11-39. Retrieved from http://link.springer.com/chapter/10.1007/978-3-642-69746-3_2

Akan, G. \& Grilo, C. (1995). Sociocultural influences on eating attitudes and behaviors, body image, and psychological functioning: A comparison of African-American, Asian-American, and Caucasian college women. International Journal of Eating Disorders, 18(2), 181-187.

Allrecipes. (2013). Retrieved from http://www.allrecipes.com American College Health Association. (2012). Healthy Campus 2020. Retrieved from http://www.acha.org/HealthyCampus/index.cfm Anding, J., Suminski, R., \& Boss, L. (2001). Dietary intake, body mass index, exercise, and alcohol: Are college women following the Dietary Guidelines for Americans? Journal of American College Health, 49, 167-171.

Arby's. (2013). Retrieved from http://www.arbys.com 
Barnes, M., Robson, P., Bonham, M., Strain, J., \& Wallace, J. (2006). Effect of vitamin D supplementation on vitamin D status and bone turnover markers in young adults. European Journal of Clinical Nutrition, 60(6), 727-733. doi:

10.1038/sj.ejcn.1602374 Retrieved from http://proxy.library.eiu.edu:2053/ ehost/pdfviewer/pdfviewer?sid=8e0864d4-0630-4a9a-a67fdc3ccaec841b\%40sessionmgr104\&vid=15\&hid=125

Bellis, M. (2013). Who Invented Facebook? Retrieved from http://inventors.about.com/od/fstartinventions/a/Facebook.htm

Bleich, S., Wang, Y., Wang. Y., \& Gortmaker, S. (2008). Increasing consumption of sugar-sweetened beverages among US adults: 1988-1994 to 1999-2004. American Society for Nutrition, 89(1), 372-381. doi: 10.3945/ajcn.2008.26883 Retrieved from http://ajcn.nutrition.org/content/89/1/372.full.pdf+html Bornstein, R. (2013). Face Validity. Retrieved from http://srmo.sagepub.com/view/the-sage-encyclopedia-of-social-scienceresearch-methods/n323.xml

Boyle, M.A. \& Holben, D.H. (2013). Community Nutrition in Action: An Entrepreneurial Approach, $6^{\text {th }}$ ed. CA: Weadsworth Cengage Learning. Brown, J. (2011). Nutrition in the Life Cycle, $4^{\text {th }}$ ed. CA: Wadsworth/Thomson Learning.

Burbary, K. (2011). Facebook Demographics Revisited - 2011 Statistics. Retrieved from http://socialmediatoday.com/kenburbary/276356/facebookdemographics-revisited-2011-statistics 
Byrnes, M. (2011). The snowball effect. Financial Planning, 41(58), 81-82. Retrieved from http://proxy1.library.eiu.edu:2075/ehost/pdfviewer/pdfviewer?sid=2b0e9a aa-f4b3-49de-8d43-f254c0afed4a\%40sessionmgr114\&vid=7\&hid=117

CancerGuide. (2001). CancerGuide: Statistics. Retrieved from http://cancerguide.org/significance.html

Cousineau, T., Goldstein, M., \& Franko, D. (2004). A collaborative approach to nutrition education for college students. Journal of American College Health, 53(2), 79-84. Retrieved from

http://proxy.library.eiu.edu:2053/ehost/pdfviewer/pdfviewer?sid=e77135 Of-1 faa-4a78- bea0-0f5343767bbe\%40sessionmgr104\&vid=3\&hid=106

Dietary Guidelines for Americans. (2012). Dietary Guidelines for Americans, 2010. Retrieved from http://health.gov/dietaryguidelines/2010.asp

Edwards, J. \& Meiselman, H. (2003). Changes in dietary habits during the first year at university. British Nutrition Foundation, 28, 21-34. Retrieved from http://proxy.library.eiu.edu:2053/ehost/pdfviewer/pdfviewer?sid=e77135 Of-1 faa-4a78- bea0-0f5343767bbe\%40sessionmgr104\&vid=5\&hid=106 Epicurious. (2013). Retrieved from http://www.epicurious.com Faust, K. (2010). I “Like” JNEB. Journal of Nutrition Education and Behavior, 42(6). 359. doi: 10.1016/j.jneb.2010.09.011 
Ganji, V., Milone, C., Cody, M., McCarty, F., \& Wang, Y. (2010). Serum vitamin D concentrations are related to depression in young adult US population: The Third National Health and Nutrition Examination Survey. International Archives of Medicine, 3, 29-36. doi: 10.1186/1755-7682-3-29 Retrieved from http://proxy.library.eiu.edu:2053/ehost/pdfviewer/pdfviewer?sid=8e0864 d4-0630-4a9a-a67f-dc3ccaec841b\%40sessionmgr104\&vid=15\&hid=125

Gans, K., Ross, E., Barner, C., Wylie-Rosett, J., McMurray, J., \& Eaton, C. (2003). REAP and WAVE: New tools to rapidly assess/discuss nutrition with patients. The American Society for Nutritional Services, 133(2), 5565-5625. Retrieved from http://jn.nutrition.org/content/133/2/556S.full.pdf+html

George, D. (2011). "Friending Facebook?" A mini-course on the use of social media by health professionals. Journal of Continuing Education in the Health Professionals, 31(3), 215-219. doi: 10.1002/chp.20129

Goetze, A. (2005). Comparison of perceived and actual nutrition needs of college-aged students. Unpublished master's thesis. Eastern Illinois University, Charleston, IL.

Goodwin, R. \& Mullan, B. (2009). Predictors of undergraduates' intention to incorporate glycaemic index into dietary behaviour. Nutrition \& Dietetics, 66, 54-59.

Grosvenor \& Smolin. (2010). Visualizing Nutrition: Everyday Choices. Hoboken, NJ: Wiley. 
Hawn, C. (2009). Take two aspirin and tweet me in the morning: How Twitter, Facebook, and other social media are reshaping health care. Report from the Field, 28(2), 361-368. doi: 10.1377/hlthaff.28.2.361

Health, Fitness and Beauty Secrets. (2013). Health, Fitness and Beauty Secrets Facebook Page. Retrieved from http://www.facebook.com/HealthFitnesandBeautySecrets

Healthy People. (2012). Healthy People 2020. Retrieved from http://healthypeople.gov/2020/default.aspx

Hoffman, D., Policastro, P., Quick, V., \& Lee, S. (2006). Changes in body weight and fat mass of men and women in the first year of college: A study of the "Freshman 15". Journal of American College Health, 55(1), 41-45.

Huang, T., Harris, K., Lee, R., Nazir, N., Born, W., \& Kaur, H. (2003). Assessing overweight, obesity, diet, and physical activity in college students. Journal of American College Health, 52(2), 83-86. Retrieved from http://proxy1.library.eiu.edu:2075/ehost/pdfviewer/pdfviewer?sid=04058 ec5-f2f2-4181-a744-f88e2f0cf8e8\%40sessionmgr112\&vid=8\&hid=108 Ison, A. (2008). Applying the Theory of Planned Behavior on consumption of fruits and vegetables among university students. Unpublished master's thesis. Eastern Illinois University, Charleston, IL.

Jackson, R., Barry, T., \& Kennedy, M. (2011). The relationship between lifestyle and campus eating behaviours in male and female university students. College Student Journal, 43(3), 860-871. Retrieved from http://proxy.library.eiu.edu: 
2053/ehost/detail?sid=2e5919f8-87d5-4d0a-9327-

3336b68a0030\%40sessionmgr115\&vid=21\&hid=123\&bdata=JnNpdGU9ZW hvc3QtbGl2ZQ\%3d\%3d\#db=a9h\&AN=43969288

Jacobs, N., Hagger, M., Streukens, S., De Bourdeaudhuji, I., \& Claes, N. (2011). Testing an integrated model of the Theory of Planned Behavior and SelfDetermination Theory for different energy balance-related behaviours and intervention intensities. British Journal of Health Psychology, 16(1), 113-134. doi: 10.1348/135910710X519305 Retrieved from http://proxy.library.eiu.edu:2053/ehost/pdfviewer/pdfviewer?sid=2fac3fe2 $-115 \mathrm{e}-4 \mathrm{c} 94-8 \mathrm{c} 67-202 \mathrm{a} 698 \mathrm{dc} 4 \mathrm{ce} \% 40$ sessionmgr 104\&vid=5\&hid $=103$

Jamison, J. (1999). Mineral deficiency: A dietary dilemma? Journal of Nutritional and Environmental Medicine, 9(2), 149-158. doi:10.1080/13590849961744 Retrieved from http://proxy.library.eiu.edu:2053/ehost/pdfviewer/ pdfviewer?sid=8e0864d4-0630-4a9a-a67f-dc3ccaec841b\% 40sessionmgr 104\&vid=10\&hid $=125$

Jenny Craig. (2013). Jenny Craig Facebook Page. Retrieved from http://www.facebook.com/jennycraig?ref=ts\&fref=ts Jimmy John's Gourmet Sandwiches. (2013). Retrieved from http://www.jimmyjohns.com Kicklighter, J., Koonce, V., Rosenbloom, C., \& Commander, N. (2010). College freshman perceptions of effective and ineffective aspects of nutrition education. Journal of American College Health, 59(2), 98-104. 
Kolodinsky, J., Labrecque, J., Doyon, M., Reynolds, T., Oble, F., Bellavance, F., \& Marquis, M. (2008). Sex and cultural differences in the acceptance of functional foods: A comparison of American, Canadian, and French college students. Journal of American College Health, 57(2), 143-149. Retrieved from http://proxy.library.eiu.edu:2053/ehost/pdfviewer/pdfviewer?sid=e77135 0f-1 faa-4a78-bea0-0f5343767bbe\%40sessionmgr104\&vid=10\&hid=106

Kuehn, B. (2011) Patients go online seeking support, practical advice on health conditions. Journal of American Medical Association, 305(16), 1644-1645.

LaChausse, R. (2012). My student body: Effects of an internet-based prevention program to decrease obesity among college students. Journal of American College Health, 60(4), 324-330.

Larson, N., Neumark-Sztainer, D., Story, M. \& Burgess-Champoux, T. (2010). Wholegrain intake correlates among adolescents and young adults: Findings from Project EAT. Journal of the American Dietetic Association, 110(2), 230-237. doi:10.1016/j.jada.2009.10.034

Louis, W., Davies, S., Smith, J., \& Terry, D. (2007) Pizza and pop and the student identity: The role of referent group norms in healthy and unhealthy eating. The Journal of Social Psychology, 147(1), 57-74. Retrieved from http://proxy.library.eiu.edu:2053/ehost/pdfviewer/pdfviewer?sid=e77135 0f-1faa-4a78-bea0-0f5343767bbe\%40sessionmgr104\&vid=13\&hid=106 Lutfiyya, M., Chang, L., \& Lipsky. M. (2012). A cross-sectional study of US rural adults' consumption of fruits and vegetables: Do they consume at least five 
servings daily? Public Health, 12, 280-296. Retrieved from http://proxy.library.eiu.edu:2053/ehost/pdfviewer/pdfviewer?sid=e77135 0f-1faa-4a78-bea0-0f5343767bbe\%40sessionmgr104\&vid=15\&hid=106 Mahan, L.K., Escott-Stump, S., \& Raymond, J.L. (2012). Krasuse's Food and the Nutrition Care Process. United States of America: Elesevier.

Malinauskas, B., Raedeke, T., Aeby, V., Smith, J., \& Dallas, M. (2006) Dieting practices, weight perceptions, and body composition: A comparison of normal weight, overweight, and obese college females. Nutrition Journal, 5(11), 11-18. doi: 10.1186/147-2891-5-11 Retrieved from http://web.ebscohost.com/ehost/detail?vid=2\&sid=067a3763-9ed0-45f78eb4- 891a15bafa97\%40sessionmgr10\&hid=28\&bdata= JnNpdGU9ZWhvc3QtbGl2ZQ\%3d\%3d\#db=a9h\&AN=30094635

Maltz, M. (1989). Psycho-Cybernetics. New York City: Pocket Books.

Martini, L., Catania, A., \& Ferreira, S. (2010). Role of vitamins and minerals in prevention and management of type 2 diabetes mellitus. Nutrition Reviews, 68(6), 341-454. doi: 10.1111/j.1753-4887.2010.00296.x

Masic, I., Sivic, S., Toromanovic, S., Borojevic, T., \& Pandza, H. (2012). Social networks in improvement of health care. Materia Socio Medica, 24(1), 48-53. doi: $10.5455 / \mathrm{ms} .2012 .24 .48-5$

McCallister, M. (2008). Effects of a health program on dietary behaviors, physical activity, and weight loss in college students. Unpublished master's thesis. Eastern Illinois University, Charleston, IL. 
McDonald's. (2013). Retrieved from http://www.mcdonalds.com

Merriam-Webster. (2012). Retrieved from http://www.merriam-webster.com/

Mihalopoulos, N., Auinger, P., \& Klein, J. (2008). The Freshman 15: Is it real? Journal of American College Health, 56(5), 531-533.

Miller, M. (2005). Best questions and tools for quickly assessing your patient's dietary health: Towards evidence-based determination of nutritional counseling need in the general medical interview. Nutrition Noteworthy, 7(1), 1-15. Retrieved from http://www.escholarship.org/uc/item/9s03p43r

Ming-Chin, Y., Matsumori, B., Obenchain, J., Viladrich, A., Das, D., \& Navder, K. (2010). Validity of a competing food choice construct regarding fruit and vegetable consumption among urban college freshman. Journal of Nutrition Education and Behavior, 42(5), 321-328. doi: 10.1016/j.jneb.2009.008.004

Morrell, J., Lofgren, I., Burke, J., \& Reilly, R. (2011). Metabolic syndrome, obesity, and related risk factors among college men and women. Journal of American College Health, 60(1), 82-89. doi: 10.1080/07448481.2011.582208. Retrieved from http://proxy.library.eiu.edu:2170/Direct.asp?AccessToken= 6V2XCL289ZZFZFM2MHFKMXC2M00M8CLM2V\&Show=0bject

Moss, S. (2008). Theory of Planned Behavior. Retrieved from http://www.psychit.com.au/Psychlopedia/article.asp?id=69

Mullie, P., Aerenhouts, D., \& Clarys, P. Demographic, socioeconomic and nutritional determinants of daily versus non-daily sugar-sweetened and artificially sweetened beverage consumption. European Journal of Clinical Nutrition, 
66(2), 150-155. doi: 10.1038/ejcn.2011.138 Retrieved from

http://proxy.library.eiu.edu:2053/ehost/pdfviewer/pdfviewer?sid=2e5919f

8-87d5-4d0a-9327-3336b68a0030\%40sessionmgr115\&vid=29\&hid=123

Murphy, M., Barraj, L., Herman, D., Cheatam, R., \& Randolph, K. (2012).

Phytonutrient intake by adults in the United States in relation to fruit and vegetable consumption. Journal of the Academy of Nutrition and Dietetics, 112(2), 222-229. doi: 10.1016/j.jada.11.08.044

MyPlate (2012). Retrieved from http://www.choosemyplate.gov/food-groups/

Nelson, M., Larson, N., Barr-Anderson, D., Neumark-Sztainer, D., \& Story, M. (2009). Disparities in dietary intake, meal patterning, and home food environments among young adult nonstudents and 2- and 4-year college students. American Journal of Public Health, 99(7), 1216-1219. doi: 10.2105/AJPH.2007.147454

Neuenschwander, L., Abbott, A., \& Mobley, A. (2013). Comparison of a web-based vs. in-person nutrition education program for low-income adults. Journal of the Academy of Nutrition and Dietetics, 113(1), 120-125. doi:

10.106/j.jand.2012.07.034

Nutrisystem. (2013). Retrieved from http://www.nutrisystem.com/ NutritionData.com. (2013). Retrieved from http://nutritiondata.self.com/ O'Leary, F., Hattersley, L., King, L., \& Allman-Farinelli, M. (2012). Sugary drink consumption behaviours among young adults at university. Nutrition \& Dietetics, 69, 119-123. doi:10.1111/j.1747-0080.2012.01583.x Retrieved 
from

http://proxy1.library.eiu.edu:2075/ehost/pdfviewer/pdfviewer?vid=14\&sid $=6 \mathrm{dd} 33 \mathrm{a} 20-\mathrm{b} 1 \mathrm{~b} 7-41 \mathrm{c6}-8 \mathrm{f73}-\mathrm{a} 956 \mathrm{acc} 98 \mathrm{fee} \% 40$ sessionmgr113\&hid=117

Oregon Department of Education. (2010). Using Split-Half Reliability With Tests.

Retrieved from

www.ode.state.or.us\%2Fteachlearn\%2Fpte\%2Fsplithalfreliability.doc\&ei=9 Kx5UsPsGcSzqAHZh4D4DQ\&usg=AFQjCNHVV7XwU1CQAFM0DespxcjGnyml $\mathrm{Mw}$

Pizza Hut. (2013). Retrieved from http://www.pizzahut.com

Poddar, K., Hosig, K., Anderson-Bill, E., Nickols-Richardson, S., \& Duncan, S. (2012). Dairy intake and related self-regulation improved in college students using online nutrition education. Journal of the Academy of Nutrition and Dietetics, 112(12), 1976-1986. doi: 10.1016/j.jand.2012.07.026

Qualtrics Labs, Inc. (2012). Qualtrics [Computer Software]. Provo, UT.

Sakane, N., Dohi, S., Sakata, K., Hagiwara, S., Morimoto, T., ..., J-VALUE Study Group. (2013). Effects of visceral fat accumulation awareness on a web-based weight-loss program: Japanese study of visceral adiposity and lifestyle information- Utilization and evaluation (J-VALUE). ISRN Obesity, 2013. Retrieved from: http://dx.doi.org/10.1155/2013/473764

Simmons, K., Connell, L., Ulrich, P., Skinner, H., Balasubramanian, M., \& Gropper, S. (2011). Body image and satisfaction for college freshman: Investigation into the fabled "Freshman 15". The International Journal of Health, 1(1), 117-126. 
Smith-Jackson, T., \& Reel, J. (2012) Freshman women and the "Freshman 15": Perspectives on prevalence and causes of college weight gain. Journal of American College Health, 60(1), 14-20. doi: dx.doi.org/10.1080/07448481.2011.555931

Statistical Package for the Social Sciences. (2012). Version 20.0, SPSS Inc., Chicago, IL.

Taco Bell. (2013). Retrieved from http://www.tacobell.com

Teng, C., Richards, R., Ryan, A., Coplen, T., Neiprasckh, C., Ohene-Opare, A., ..., \& Ameh, L. (2009). An interactive online education system for the supplemental nutrition program. Journal of Systematics, Cybernetics, \& Informatics, 7(6), 25-29. Retrieved from http://proxy1.library.eiu.edu:2075/ehost/pdfviewer/pdfviewer?sid=04058 ec5-f2f2-4181-a744-f88e2f0cf8e8\%40sessionmgr112\&vid=12\&hid=108

The Academy of Nutrition and Dietetics. (2013). The Academy of Nutrition and Dietetics Facebook Page. Retrieved from http://www.facebook.com/AcademyofNutritionandDietetics?ref=ts\&fref=ts USDA NAL. (2013). DRI Tables. Retrieved from http://fnic.nal.usda.gov/dietaryguidance/dietary-reference-intakes/dri-tables USDA. (2012). MyPlate. Retrieved from http://www.cnpp.usda.gov/myplate.htm Watts, M., Hager, M., Toner, C., \& Weber, J. (2011) The art of translating nutritional science into dietary guidance: History and evolution of the Dietary 
Guidelines for Americans. Nutrition Reviews, 69(7), 404-412. doi: 10.1111/j.1753-4887.2011.00408.x

Weight Loss. (2013). Weight Loss Facebook Page. Retrieved from http://www.facebook.com/weightloss4all

Weight Watchers. (2013). Weight Watchers Facebook Page. Retrieved from http://www.facebook.com/weightwatchers?fref=ts

West, D., Bursac, Z., Quimby, D., Prewitt, T., Spatz, T., Nash, C., ..., \& Eddings, K. (2012). Self-reported sugar-sweetened beverage intake among college students. Obesity, 14(10), 1825-1831. doi: 10.1038/oby.2006.210 Retrieved from http://onlinelibrary.wiley.com/doi/10.1038/oby.2006.210/full

Wharton, C., Adams, T., \& Hampl, J. (2008). Weight loss practices and body weight perceptions among US college students. Journal of College Health, 56(5), 579584.

Widrich, L. (2013). Social media in 2013: User demographics for Twitter, Facebook, Pinterest, and Instagram. Retrieved from http://blog.bufferapp.com/socialmedia-in-2013-user-demographics-for-twitter-facebook-pinterest-andinstagram

Zeevi, D. (2013). The Ultimate History of Facebook [INFOGRAPHIC]. Retrieved from http://socialmediatoday.com/daniel-zeevi/1251026/ultimate-historyfacebook-infographic 


\section{Appendix A}

\section{DAY ONE}

Nutrition Education: Crockpots can be a College Student's Life Support!

By planning your meal the night before and using a crockpot, you get a nice, hot meal upon your arrival home (and leftovers for lunch the next day). Visit your local supercenter and purchase a crockpot for \$15-20. You will use it again and again!

Recipe: Crockpot Pork Roast

Ingredients:

$1 \mathrm{lb}$. pork roast

$1 / 2 \mathrm{lb}$. baby carrots

2 medium sized russet potatoes, peeled and chopped

1 medium onion, half-moon sliced

1 packet pot roast seasoning

2 cups low-sodium beef or chicken broth

1 tsp salt

1 tsp black pepper

\section{Directions:}

1. Trim the fat off of the pork roast.

2. Place pork roast, pot roast seasoning packet, low-sodium beef/chicken broth, salt, and pepper in a crockpot placed on high for 4 hours.

3. Add potatoes, carrots, and onions and cook on low to medium heat for an additional 2 to 3 hours.

Serves 4. 


\begin{tabular}{|c|c|}
\hline \multicolumn{2}{|c|}{ Nutrition Facts } \\
\hline \multicolumn{2}{|l|}{ Calories 370} \\
\hline \multicolumn{2}{|r|}{ \% Daily Value } \\
\hline Total Fat $13 \mathrm{~g}$ & $20 \%$ \\
\hline Saturated Fat $4 \mathrm{~g}$ & $20 \%$ \\
\hline \multicolumn{2}{|l|}{ Trans Fat $0 \mathrm{~g}$} \\
\hline \multicolumn{2}{|l|}{ Cholesterol $91 \mathrm{mg}$} \\
\hline Sodium $451 \mathrm{mg}$ & $19 \%$ \\
\hline Carbohydrate $26 \mathrm{~g}$ & $9 \%$ \\
\hline Dietary Fiber $3 \mathrm{~g}$ & $14 \%$ \\
\hline \multicolumn{2}{|l|}{ Sugars $4 \mathrm{~g}$} \\
\hline \multicolumn{2}{|l|}{ Protein $36 \mathrm{~g}$} \\
\hline Vitamin A 155\% & Vitamin C $15 \%$ \\
\hline Calcium $7 \%$ & $18 \%$ \\
\hline
\end{tabular}




\section{DAY TWO}

Nutrition Education: Eating Under the Sea

Fish is a low-fat protein and offers omega- 3 fatty acids, calcium, and vitamin D, all of which promotes a healthy heart! Try to get 2 servings of fish this week; try this recipe and a tuna salad sandwich for lunch one day would be great!

Recipe: Pan-seared Tilapia with Brown Rice and steamed California blend vegetables

Ingredients:

2 tilapia fillets

$1 \mathrm{~T}$ lemon juice

$1 / 2$ tsp salt

1 tsp black pepper

1 cup instant brown rice

2 cups water

1 cup frozen California blend vegetables

1 T olive oil

Directions:

1. For the instant brown rice, follow the packages directions.

2. While the rice is cooking, heat $1 / 2 \mathrm{~T}$ olive oil in a saute pan on medium heat. Sauté the frozen California blend vegetables for 10-15 minutes or until fork tender.

3. Season the tilapia fillets with lemon juice, salt, and black pepper.

4. Heat $1 / 2 \mathrm{~T}$ olive oil in another sauté pan on medium heat for 2 minutes.

5. Gently place the fish in the heated saute pan, laying the fish away from you.

6. Cook the fish on both sides for 2-3 minutes each, the fish should look opaque and flake when cooked through.

7. Plating tip: Place $1 / 2$ cup of brown rice in the center of the plate, gently place the fish on top of the rice, and serve with the veggies on the side.

Serves 2. 


\begin{tabular}{|c|c|}
\hline Nutrition Fa & \\
\hline Calories 472 & \\
\hline & $\%$ Daily Value \\
\hline Total Fat $8 \mathrm{~g}$ & $12 \%$ \\
\hline Saturated Fat $2 \mathrm{~g}$ & $8 \%$ \\
\hline Trans Fat $0 \mathrm{~g}$ & \\
\hline Cholesterol $42 \mathrm{mg}$ & $14 \%$ \\
\hline Sodium $66 \mathrm{mg}$ & $3 \%$ \\
\hline Carbohydrate $75 \mathrm{~g}$ & $25 \%$ \\
\hline Dietary Fiber $6 \mathrm{~g}$ & $23 \%$ \\
\hline Sugars $2 \mathrm{~g}$ & \\
\hline Protein $26 \mathrm{~g}$ & \\
\hline Vitamin A $0 \%$ & Vitamin C 53\% \\
\hline Calcium $\quad 5 \%$ & Iron $\quad 12 \%$ \\
\hline
\end{tabular}




\section{DAY THREE}

Nutrition Education: It's Okay to Veg Out!

A serving of this recipe offers 2 of the 5 recommended daily servings of vegetables and is a good source of fiber and essential vitamins $C$ and E! Regular intake of fiber and vitamins $\mathrm{C}$ and $\mathrm{E}$ can reduce the risk of cancer.

For more information on vegetables, please visit:

http://www.choosemyplate.gov/food-groups/vegetables.html

Recipe: Chicken Vegetable Bake

Ingredients:

12 oz. chicken, diced into bite size pieces

1 medium onion, sliced thin

1 bell pepper, sliced thin

$3 / 4$ cup frozen broccoli

$12 \mathrm{oz}$. whole wheat pasta (rotini, shells, elbow)

1 jar spaghetti sauce

$1 \frac{1}{2} \mathrm{c}$ low-fat cheese, shredded

Salt and pepper to taste

$1 \mathrm{~T}$ garlic powder

1 T Olive oil

\section{Directions:}

1. Preheat oven to $375 F$.

2. Heat olive oil in pan.

3. In a sauce pan, boil water for pasta. Once water is boiling, cook pasta to desired doneness and drain. While pasta is cooking, continue with the next part.

4. Once oil is hot, sauté chicken for 3 minutes. Season with salt, pepper, and garlic powder.

5. Add in onions and bell peppers, sauté for an additional 3 minutes.

6. Add broccoli, sauté for an additional 2-3 minutes.

7. In a baking pan, combine pasta, spaghetti sauce, chicken and vegetables and stir. Top with shredded cheese.

8. Bake for 15-20 minutes or until cheese is brown and bubbly.

Serves 4. 


\begin{tabular}{|c|c|}
\hline \multicolumn{2}{|l|}{ Nutrition Facts } \\
\hline Calories 442 & \\
\hline & \% Daily Value \\
\hline Total Fat $16 \mathrm{~g}$ & $24 \%$ \\
\hline Saturated Fat $6 \mathrm{~g}$ & $28 \%$ \\
\hline Trans Fat $0 \mathrm{~g}$ & \\
\hline Cholesterol $90 \mathrm{mg}$ & $30 \%$ \\
\hline Sodium $696 \mathrm{mg}$ & $29 \%$ \\
\hline Carbohydrate $36 \mathrm{~g}$ & $12 \%$ \\
\hline Dietary Fiber $9 \mathrm{~g}$ & $37 \%$ \\
\hline Sugars $10 \mathrm{~g}$ & \\
\hline Protein $38 \mathrm{~g}$ & \\
\hline Vitamin A $176 \%$ & Vitamin C $27 \%$ \\
\hline Calcium $\quad 41 \%$ & Iron $\quad 19 \%$ \\
\hline
\end{tabular}




\section{DAY FOUR}

Nutrition Education: Protein, not just from Steak

It is important to get about 5-6 ounces of protein a day. That looks like 2 deck of cards ( 1 deck $=3$ oz. of meat). Protein can come from meat and poultry sources, but it can also come from beans, nuts, peanut butter, and soy products, like tofu or veggie burgers.

To learn how to select, pit and peel an avocado, please watch this YouTube video: http://www.youtube.com/watch?v=bKVgqFEUnuU

For more information on protein, please visit:

http://www.choosemyplate.gov/food-groups/protein-foods.html

Recipe: Black Bean Tacos

Ingredients:

1 T olive oil

1 small onion, chopped

15 oz. can black beans, rinsed and drained

7 oz. can green salsa

$1 / 2$ tsp garlic powder

$1 / 2$ tsp ground cumin

6 taco shells

1 tomato, diced (optional)

1 avocado, sliced (optional)

1 cup shredded lettuce (optional)

\section{Directions:}

1. Heat olive oil in a saucepan over medium-low heat.

2. Cook onion in hot oil until tender, about 5 minutes. Stir black beans, green salsa, garlic powder, and cumin with the onion.

3. Reduce heat to low and cook the mixture at a simmer until it thickens, $\mathbf{5}$ to 10 minutes.

4. Serve with taco shells, tomato, avocado, and shredded lettuce.

Serves 4. 


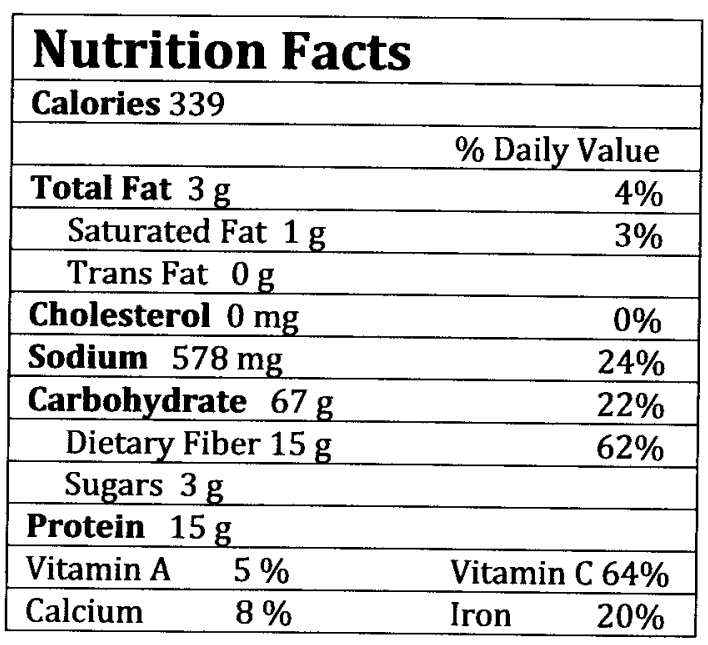




\section{DAY FIVE}

Nutrition Education: Sweet Tooth?! Incorporate Fruit into Your Meals

Try fruits instead of desserts next time you have a craving for something sweet. You can try either a bowl of mixed berries or vanilla yogurt with bananas for dessert. You will consume less fat, refined sugar, and calories this way.

For more information on fruit, please visit: http://www.choosemyplate.gov/foodgroups/fruits.html

Recipe: Honey Chicken with Green Salad with Strawberry Balsamic Vinaigrette

Ingredients:

$1 / 2$ cup orange juice

$1 \mathrm{~T}$ lemon juice

$1 / 8$ cup olive oil

$1 / 4$ cup honey

1 boneless chicken breast

1 tsp strawberry jam

$1 / 2 \mathrm{~T}$ balsamic vinegar

$1 \frac{1}{2} \mathrm{~T}$ olive oil

$3 / 4$ cup strawberries, sliced

2 cup mixed greens

Directions:

1. Combine orange juice, lemon juice, olive oil, honey, and chicken breast in a large plastic bag. Marinate for 1 to 2 hours.

2. Preheat oven to 350F. Bake chicken for 20 minutes.

3. Whisk together strawberry jam, balsamic vinegar, and olive oil.

4. Slice the chicken breasts.

5. Toss the mixed greens, strawberries, and vinaigrette. Top with sliced chicken.

Serves 2. 


\begin{tabular}{|c|c|}
\hline Nutrition Fa & \\
\hline Calories 423 & \\
\hline & \% Daily Value \\
\hline Total Fat $16 \mathrm{~g}$ & $25 \%$ \\
\hline Saturated Fat $2 \mathrm{~g}$ & $12 \%$ \\
\hline Trans Fat $\mathbf{0} \mathbf{g}$ & \\
\hline Cholesterol $78 \mathrm{mg}$ & $26 \%$ \\
\hline Sodium $99 \mathrm{mg}$ & $4 \%$ \\
\hline Carbohydrate $39 \mathrm{~g}$ & $13 \%$ \\
\hline Dietary Fiber $1 \mathrm{~g}$ & $5 \%$ \\
\hline Sugars $36 \mathrm{~g}$ & \\
\hline Protein $32 \mathrm{~g}$ & \\
\hline Vitamin A $\quad 45 \%$ & Vitamin C $72 \%$ \\
\hline Calcium & Iron \\
\hline
\end{tabular}


DAY SIX

Nutrition Education: Grains! Grains! Every day!

It is important to get at least 3 servings of whole grains every day. You can try brown rice, whole wheat pasta, oatmeal, and wheat bread. Whole grains offer magnesium, iron, and fiber and helps to reduce the risk of heart disease and diabetes.

For more information on grains, please visit: http://www.choosemyplate.gov/foodgroups/grains.html

Recipe: Pork Chops with Steamed Broccoli and Whole Wheat Dinner Roll

Ingredients:

$1 \mathrm{~T}$ lemon juice

$1 \mathrm{~T}$ vegetable oil

$1 / 8$ tsp garlic powder

2 boneless pork chops

1 cup frozen broccoli

$1 / 2$ tsp salt

1 tsp black pepper

2 whole wheat dinner rolls

$1 \mathrm{~T}$ olive oil

Directions:

1. In a bowl, mix the lemon juice, vegetable oil, and garlic powder. Set aside some of the mixture in a separate bowl for marinating during cooking. Pierce the pork chops on both sides with a fork, place in a large resealable plastic bag, and cover with the remaining marinade mixture. Refrigerate 6 to 8 hours, or overnight.

2. Heat olive oil in a sauté pan on medium-high heat on stove.

3. Bring $3 / 4$ to 1 inch of water to a boil in a saucepan with a steamer. (Note that is you don't have a steamer, you can simply put the broccoli directly into an inch of boiling water.) Add the broccoli to the steamer and cover; reduce heat to medium and let cook for 5-6 minutes. The broccoli is done when you can pierce it with a fork. But be careful not to overcook the broccoli. As soon as it is pierce-able, remove from heat, place in serving dish. Season broccoli with salt and pepper.

4. Sear pork chops six to eight minutes on each side, or to desired doneness.

Serves 2 . 


\begin{tabular}{|c|c|}
\hline Nutrition Fa & \\
\hline Calories 570 & \\
\hline & $\%$ Daily Value \\
\hline Total Fat $17 \mathrm{~g}$ & $27 \%$ \\
\hline Saturated Fat $\mathbf{4} \mathrm{g}$ & $19 \%$ \\
\hline Trans Fat $2 \mathrm{~g}$ & \\
\hline Cholesterol $61 \mathrm{mg}$ & $20 \%$ \\
\hline Sodium $975 \mathrm{mg}$ & $41 \%$ \\
\hline Carbohydrate $60 \mathrm{~g}$ & $20 \%$ \\
\hline Dietary Fiber $8 \mathrm{~g}$ & $33 \%$ \\
\hline Sugars $14 \mathrm{~g}$ & \\
\hline Protein $15 \mathrm{~g}$ & \\
\hline Vitamin $\mathrm{A} \quad 18 \%$ & Vitamin C $88 \%$ \\
\hline Calcium $\quad 11 \%$ & Iron $\quad 20 \%$ \\
\hline
\end{tabular}




\section{DAY SEVEN}

Nutrition Education: Your Eyes are A-Okay with Vitamin A

Vitamin A plays a major role in eye health. Orange and yellow fruits and vegetables, such as cantaloupe, sweet potatoes, carrots, grapefruit, and yellow squash, are excellent sources of Vitamin A. Try to eat one of these at least five days a week. For more information on Vitamin A, please visit: http://ods.od.nih.gov/factsheets/VitaminA-QuickFacts/

Recipe: Crockpot BBQ Beef Sandwiches with Baked Sweet Potato and Yogurt with Mixed Berries

Ingredients:

$1 \mathrm{lb}$. rump roast

$6 \mathrm{oz}$. root beer

1 cup honey BBQ sauce

4 whole wheat buns

4 sweet potatoes

4 cups vanilla yogurt

1 cups frozen mixed berries

Directions:

1. In a crockpot, combine the rump roast, root beer, and honey BBQ sauce. Cook on high heat for 3 hours; reduce to medium heat and continue to cook for 3 more hours.

2. Cook sweet potatoes in microwave for 6 minutes or until tender (optional: top with 1 tsp butter and 1 tsp brown sugar each)

3. Top 1 cup of yogurt with $1 / 4$ cup of frozen mixed berries

4. Serve BBQ on a whole wheat bun. Enjoy with a sweet potato and a yogurt parfait.

Serves 4. 


\begin{tabular}{|c|c|}
\hline Nutrition Fa & \\
\hline Calories 688 & \\
\hline & \% Daily Value \\
\hline Total Fat $20 \mathrm{~g}$ & $30 \%$ \\
\hline Saturated Fat $8 \mathrm{~g}$ & $38 \%$ \\
\hline Trans Fat $\mathbf{0 g}$ & \\
\hline Cholesterol $85 \mathrm{mg}$ & $28 \%$ \\
\hline Sodium $409 \mathrm{mg}$ & $17 \%$ \\
\hline Carbohydrate $87 \mathrm{~g}$ & $29 \%$ \\
\hline Dietary Fiber $8 \mathrm{~g}$ & $33 \%$ \\
\hline Sugars $42 \mathrm{~g}$ & \\
\hline Protein $40 \mathrm{~g}$ & \\
\hline Vitamin A $333 \%$ & Vitamin C $43 \%$ \\
\hline Calcium & $24 \%$ \\
\hline
\end{tabular}




\section{DAY EIGHT}

Nutrition Education: Reducing Sodium is Heart Friendly

Look for ways to reduce sodium in your everyday diet to help maintain a healthy blood pressure. You can do this by eating more meals at home, choosing frozen vegetables over canned, choosing lower-sodium options for cheese, soups, vegetables, etc., and use other seasonings in your meals like herbs and lemon juice. For more information on sodium, please visit:

http://www.heart.org/HEARTORG/GettingHealthy/NutritionCenter/HealthyDietGo als/Sodium-Salt-or-Sodium-Chloride_UCM_303290_Article.jsp

Recipe: Hamburger and Sweet Potato Fries to be compared with McDonald's Quarter Pounder with Cheese Value Meal

Ingredients:

$1 / 2 \mathrm{lb}$. lean hamburger

$1 / 2$ tsp salt

1 tsp black pepper

2 tsp chili powder (optional)

2 slices of your favorite cheese

2 whole wheat hamburger buns

$1 / 2 \mathrm{lb}$. sweet potato fries

$2 \mathrm{~T}$ ketchup

Directions:

1. Preheat oven to 350F.

2. Combine hamburger, salt, black pepper, and chili powder. Form into two hamburger patties.

3. Bake sweet potato fries for $\mathbf{1 5}$ to $\mathbf{2 0}$ minutes or until desired crispness has been reached.

4. Heat a skillet over medium high heat on stove. Cook the hamburger patties for 4 to 5 minutes on each side or until desired doneness.

5. Melt cheddar cheese on burgers.

6. Serve on whole wheat hamburger buns and with sweet potato fries. Can enjoy with ketchup.

Serves 2. 
Home cooked versus McDonald's

\begin{tabular}{|l|l|}
\hline Calories 600 & Calories 750 \\
\hline Fat $21 \mathrm{~g}$ & Fat $38 \mathrm{~g}$ \\
\hline Saturated Fat $8 \mathrm{~g}$ & Saturated Fat 14 g \\
\hline Trans Fat $1 \mathrm{~g}$ & Trans Fat $1.5 \mathrm{~g}$ \\
\hline Cholesterol $107 \mathrm{mg}$ & Cholesterol $95 \mathrm{mg}$ \\
\hline Sodium $501 \mathrm{mg}$ & Sodium $1270 \mathrm{mg}$ \\
\hline
\end{tabular}




\section{DAY NINE}

Nutrition Education: More Vegetables=More Weight Loss

Get your five servings of vegetables a day! By "sneaking" in vegetables into your everyday meals you will consume fewer calories and more nutrients and fiber. This can lead to a shrinking waist line. Put more veggies on your sandwich, add some to your pasta or pizza, or you could bulk up soup with veggies.

For more information on obesity and prevention, please visit: http://www.cdc.gov/healthyweight/effects/

Recipe: Turkey Vegetable Pizza to be compared with Large Pizza Hut's Pan Pepperoni Pizza

Ingredients:

1 whole wheat pizza crust

1 cup pizza sauce

2 cups low-fat mozzarella cheese

15 oz. ground turkey

$1 / 2$ green bell pepper, sliced thin

$1 / 2$ white onion, sliced thin

1 cup sliced mushrooms

\section{Directions:}

1. Preheat oven to 400F.

2. On the stove in a skillet, brown the ground turkey over medium heat.

3. Spread pizza sauce even on whole wheat pizza crust.

4. Top pizza with cheese, turkey, bell pepper, onion, and mushrooms.

5. Bake for $\mathbf{1 5}$ minutes or until cheese is brown and bubbly.

Serves 4.

Home Cooked versus Pizza Hut

\begin{tabular}{|l|l|}
\hline Calories 568 & Calories 740 \\
\hline Fat $19 \mathrm{~g}$ & Fat $38 \mathrm{~g}$ \\
\hline Saturated Fat $4 \mathrm{~g}$ & Saturated Fat $14 \mathrm{~g}$ \\
\hline Trans Fat $0 \mathrm{~g}$ & Trans Fat $0 \mathrm{~g}$ \\
\hline Cholesterol $124 \mathrm{mg}$ & Cholesterol $70 \mathrm{mg}$ \\
\hline Sodium $1054 \mathrm{mg}$ & Sodium $1780 \mathrm{mg}$ \\
\hline
\end{tabular}




\section{DAY TEN}

Nutrition Education: Plan Ahead and Pack your Lunch

School schedules get busy and it is easy to eat out with friends regularly. However, that increases your intake of calories, fat, cholesterol, and sodium, which lead to weight gain. So I challenge you to plan ahead for tomorrow and pack your lunch. Keep it simple: sandwich, baked chips, an apple, and a bottle of water.

For more information on reducing fat in meals, please visit:

http://my.clevelandclinic.org/healthy_living/weight_control/hic_reducing_fat_intak e.aspx

Recipe: Turkey Sandwich on Whole Wheat Hoagie and Baked Potato Chips to be compared with Jimmy John's \#4 Turkey Tom and Potato Chips

Ingredients:

1 whole wheat hoagie bun

2 oz. turkey lunch meat

1 slice cheese

$1 / 4$ cup shredded lettuce

$1 / 4$ cup cucumber, sliced

2 tomato slices

1 T Dijon mustard

1 oz. or 15 baked potato chips

1 apple

Directions:

1. Assembly turkey, cheese, lettuce, cucumber, tomato on the whole wheat hoagie bun. Top with Dijon mustard.

2. Enjoy with baked potato chips and an apple.

Serves 1.

Home Cooked versus Jimmy John's

\begin{tabular}{|l|l|}
\hline Calories 543 & Calories 676 \\
\hline Fat $27 \mathrm{~g}$ & Fat $30 \mathrm{~g}$ \\
\hline Saturated Fat $8 \mathrm{~g}$ & Saturated Fat $5 \mathrm{~g}$ \\
\hline Trans Fat $0 \mathrm{~g}$ & Trans Fat $0 \mathrm{~g}$ \\
\hline Cholesterol $80 \mathrm{mg}$ & Cholesterol $38 \mathrm{mg}$ \\
\hline Sodium $833 \mathrm{mg}$ & Sodium $1174 \mathrm{mg}$ \\
\hline
\end{tabular}




\section{DAY ELEVEN}

Nutrition Education: Don't Make a Trans Fat Mistake

Swap out your greasy fast food sides for healthier alternatives. Munch on a side salad, soup, baked potato, baked fries, some fruit (canned, frozen, or fresh), or a yogurt parfait. This helps keep your trans fat intake to a minimum.

For more information on trans fats, please visit:

http://www.heart.org/HEARTORG/GettingHealthy/FatsAndOils/Fats101/TransFats_UCM_301120_Article.jsp

Recipe: Hot Roast Beef Sandwich with a Side Salad and Italian Vinaigrette to be compared with Arby's Classic Beef'n Cheddar Value Meal

Ingredients:

Non-stick pan spray (such as Pam)

1 whole wheat hamburger bun

$2 \mathrm{oz}$. roast beef

1 slice cheddar cheese

1 tomato slice

1 romaine lettuce leaf

1 cup salad mix, complete with added veggies

$2 \mathrm{~T}$ Italian vinaigrette

Directions:

1. Spray a skillet with non-stick pan spray and place on stove on medium heat.

2. Once skillet is hot, place the hamburger bun face down and the roast beef in skillet.

3. Once roast beef is warm, place the cheddar cheese slice on it; allow 1 minute to melt.

4. Remove roast beef and bun from skillet and assembly sandwich with lettuce and tomato slice

5. Toss together the romaine lettuce, shredded carrots, cucumbers, grape tomatoes, and Italian vinaigrette.

Serves 1.

Home cooked versus Arby's

\begin{tabular}{|l|l|}
\hline Calories 508 & Calories 540 \\
\hline Fat $25 \mathrm{~g}$ & Fat $25 \mathrm{~g}$ \\
\hline Saturated Fat $6 \mathrm{~g}$ & Saturated Fat $6 \mathrm{~g}$ \\
\hline Trans Fat $0 \mathrm{~g}$ & Trans Fat $1 \mathrm{~g}$ \\
\hline Cholesterol $76 \mathrm{mg}$ & Cholesterol $75 \mathrm{mg}$ \\
\hline Sodium $946 \mathrm{mg}$ & Sodium $1600 \mathrm{mg}$ \\
\hline
\end{tabular}




\section{DAY TWELVE}

Nutrition Education: Food is Fun with Friends

It's Mexican night! Invite some friends over tonight to cook with you and share this delicious, low-fat recipe. Cooking is always more fun when you have others to share it with!

To find more recipes to cook with your friends, visit: www.allrecipes.com or www.epicurious.com

Recipe: Black Bean Burrito with Chips and Salsa to be compared with Taco Bell's 7layer Burrito with Chips and Pico de Gallo

Ingredients:

4 whole wheat tortillas

$2 \mathrm{~T}$ vegetable oil

1 white onion

$1 / 2$ green bell pepper

$1 \mathrm{~T}$ garlic powder

15 oz. canned black beans

1 jalapeno pepper

3 ounces fat-free cream cheese

$1 / 2$ tsp salt

4 oz. corn tortilla chips

1 cup mild salsa

Directions:

1. Wrap tortillas in foil and place in oven heated to 350 degrees F (175 degrees C). Bake for 15 minutes or until heated through.

2. Heat oil in a 10-inch skillet over medium heat. Place onion, bell pepper, garlic and jalapenos in skillet, cook for 2 minutes stirring occasionally. Pour beans into skillet, cook 3 minutes stirring.

3. Cut cream cheese into cubes and add to skillet with salt. Cook for 2 minutes stirring occasionally. Stir cilantro into mixture.

4. Spoon mixture evenly down center of warmed tortilla and roll tortillas up. Serve immediately.

5. Enjoy with chips and salsa

Serves 4 . 
Home Cooked versus Taco Bell

\begin{tabular}{|l|l|}
\hline Calories 599 & Calories 905 \\
\hline Fat 13 g & Fat 19.5 g \\
\hline Saturated Fat 2 g & Saturated Fat 8 g \\
\hline Trans Fat 0 g & Trans Fat 0 g \\
\hline Cholesterol 3 mg & Cholesterol 20 mg \\
\hline Sodium $359 \mathrm{mg}$ & Sodium 1850 mg \\
\hline
\end{tabular}




\section{DAY THIRTEEN}

Nutrition Education: Sugar- Not Always the Sweetest Choice

Dessert is fine, but like everything else it must be enjoyed in moderation. Look for reduced sugar, lower-fat options. Always add some fruit into the mix to get some added vitamins and minerals.

For more information on sugar and the prevention of diabetes, please visit:

http://www.diabetes.org/diabetes-basics/prevention/

Recipe: Frozen Greek Yogurt with Fresh Fruit and Chocolate Chips to be compared with a small Dairy Queen's Choco Cherry Love Blizzard

Ingredients:

1 cup frozen Greek vanilla yogurt

$1 / 3$ cup strawberries, sliced

$1 / 3$ cup berries (raspberries, blackberries, or blueberries)

$1 / 4$ cup dark chocolate chips

Directions:

1. In a bowl, top your frozen Greek yogurt with berries and chocolate chips.

Serves 1.

Home Cooked versus Dairy Queen

\begin{tabular}{|l|l|}
\hline Calories 425 & Calories 560 \\
\hline Fat $16 \mathrm{~g}$ & Fat $20 \mathrm{~g}$ \\
\hline Saturated Fat $9 \mathrm{~g}$ & Saturated Fat $14 \mathrm{~g}$ \\
\hline Trans Fat $0 \mathrm{~g}$ & Trans Fat $1 \mathrm{~g}$ \\
\hline Cholesterol $4 \mathrm{mg}$ & Cholesterol $55 \mathrm{mg}$ \\
\hline Sugar $45 \mathrm{~g}$ & Sugar $70 \mathrm{~g}$ \\
\hline
\end{tabular}




\section{DAY FOURTEEN}

Nutrition Education: Step Away from Added Butter and Save Your Waistline

Everyone likes going to the movies or having a movie night at home with friends and that means movie snacks. To help stay healthy opt for lower calorie, reduced fat snacks. Other healthy snacks can include trial mix, whole wheat crackers, dark chocolate candy, and $100 \%$ fruit snacks. Always stick to water and leave the Icee and soda alone.

For more tips on avoiding added calories and fat, please visit: http://www.choosemyplate.gov/weight-management-calories/weightmanagement/better-choices/fewer-calories.html

Recipe: Water, Pretzels, and Popcorn to be compared with AMC Showplace's Icee, Nachos, and Buttered Popcorn

Ingredients:

1 bottle water

1 oz. pretzels (about 10 twists)

$3 \mathrm{c} \mathrm{lightly-buttered} \mathrm{popcorn}$

Directions:

1. Pack your purse/bag with healthy snacks such as pretzels and bring a bottle of water to enjoy during the movie.

2. When ordering movie at the theater, request little or no butter and do not add your own.

Home Cooked versus AMC Showplace

\begin{tabular}{|l|l|}
\hline Calories 419 & Calories 2085 \\
\hline Fat $16 \mathrm{~g}$ & Fat $90 \mathrm{~g}$ \\
\hline Saturated Fat $3 \mathrm{~g}$ & Saturated Fat $45 \mathrm{~g}$ \\
\hline Trans Fat $0 \mathrm{~g}$ & Trans Fat $0 \mathrm{~g}$ \\
\hline
\end{tabular}




\section{DAY FIFTEEN}

Nutrition Education: Fuel Your Day the Right Way

Breakfast is the only way to start your day the right way. Breakfast wakes up your metabolism and helps to start burning fat and calories immediately. Without a good breakfast, your metabolism lags and can lead to weight gain.

For more information on the importance of breakfast, please visit:

http://mydoctor.kaiserpermanente.org/ncal/Images/Importance\%20of\%20Eating \%20a\%20Good\%20Breakfast\%20\%286909-E\%29_tcm75-14514.pdf

Recipe: Oatmeal and Turkey Bacon

Ingredients:

$1 / 2$ cup oatmeal, quick oats

$1 \mathrm{~T}$ chopped walnuts

$1 / 4$ cup dried cranberries

$1 \mathrm{~T}$ brown sugar

$1 / 4$ cup skim milk

1 slice turkey bacon

\section{Directions:}

1. In a sauté pan, cook the turkey bacon over medium heat until desired doneness.

2. Follow microwave preparation for the quick oat oatmeal.

3. Dress oatmeal with walnuts, cranberries, brown sugar, and skim milk. 


\begin{tabular}{|c|c|}
\hline \multicolumn{2}{|c|}{ Nutrition Facts } \\
\hline \multicolumn{2}{|l|}{ Calories 458} \\
\hline \multicolumn{2}{|r|}{ \% Daily Value } \\
\hline Total Fat $12 \mathrm{~g}$ & $19 \%$ \\
\hline Saturated Fat $2 \mathrm{~g}$ & $11 \%$ \\
\hline \multicolumn{2}{|l|}{ Trans Fat $0 \mathrm{~g}$} \\
\hline Cholesterol $17 \mathrm{mg}$ & $6 \%$ \\
\hline Sodium $405 \mathrm{mg}$ & $17 \%$ \\
\hline Carbohydrate $79 \mathrm{~g}$ & $26 \%$ \\
\hline Dietary Fiber $7 \mathrm{~g}$ & $28 \%$ \\
\hline \multicolumn{2}{|l|}{ Sugars $43 \mathrm{~g}$} \\
\hline \multicolumn{2}{|l|}{ Protein $14 \mathrm{~g}$} \\
\hline Vitamin A $\quad 0 \%$ & Vitamin C $\quad 1 \%$ \\
\hline Calcium & $15 \%$ \\
\hline
\end{tabular}




\section{DAY SIXTEEN}

Nutrition Education: Plan Ahead and Have a Delicious Start!

Think about breakfast the night before and have ingredients ready to go. Chop veggies for your breakfast sandwich or omelet the night before and leave in the fridge. Lay out the skillet and other ingredients so you can have a warm, healthy breakfast in just 5 minutes!

For more healthy and quick breakfast recipes, please visit:

http://www.realsimple.com/food-recipes/recipe-collections-favorites/healthymeals/breakfast-to-go-10000001047596/index.html

Recipe: Breakfast Sandwich with a Banana

Ingredients:

1 whole wheat English muffin

$1 / 2$ green bell pepper

2 egg whites

1 slice cheddar cheese

1 medium banana

Non-stick pan spray

Directions:

1. Lightly dust a sauté pan on the stove and turn on medium heat.

2. Sauté the green bell pepper for 2 minutes and then add egg whites. Do not stir. Flip once.

3. Once egg whites have cooked through, fold in half and place the cheddar cheese slice.

4. While the cheese is melting, toast the whole wheat English muffin to desired doneness.

5. Assemble the sandwich and enjoy with a banana.

Serves 1. 


\begin{tabular}{|lr|}
\hline \multicolumn{2}{|l|}{ Nutrition Facts } \\
\hline \multicolumn{2}{|l|}{ Calories 330 } \\
\hline \multicolumn{2}{|c|}{$\%$ Daily Value } \\
\hline Total Fat $4 \mathrm{~g}$ & $6 \%$ \\
\hline Saturated Fat $2 \mathrm{~g}$ & $8 \%$ \\
\hline Trans Fat $0 \mathrm{~g}$ & $2 \%$ \\
\hline Cholesterol $6 \mathrm{mg}$ & $29 \%$ \\
\hline Sodium 690 $\mathrm{mg}$ & $19 \%$ \\
\hline Carbohydrate $58 \mathrm{~g}$ & $35 \%$ \\
\hline Dietary Fiber $9 \mathrm{~g}$ & \\
\hline Sugars $22 \mathrm{~g}$ & \\
\hline Protein $32 \mathrm{~g}$ & \\
\hline Vitamin A $8 \%$ & Vitamin C $117 \%$ \\
\hline Calcium $31 \%$ & Iron \\
\hline \multicolumn{2}{|c}{$13 \%$} \\
\hline
\end{tabular}




\section{DAY SEVENTEEN}

Nutrition Education: Happy Bones, Happy Heart, Happy Calcium

Stock up your body's store of calcium. Your bones stop absorbing calcium by age 30 . So do yourself a favor and eat three servings of dairy a day. Stock your fridge with low-fat cheese, yogurt, cottage cheese, and low-fat or non-fat milk.

For more information on calcium, please visit:

http://www.eatright.org/Public/content.aspx?id=6794\&terms=calcium

Recipe: Whole Wheat Toast and Yogurt Parfait

Ingredients:

2 slices whole wheat toast

$2 \mathrm{~T}$ strawberry preserves

1 cup yogurt, your favorite flavor

$1 / 4 \mathrm{c}$ frozen mixed berries

$1 / 4$ c granola

Directions:

1. Toast bread to desired doneness. Top with strawberry preserves.

2. Combine yogurt, mixed berries, and granola for the parfait.

3. Enjoy together.

Serves 1.

\begin{tabular}{|c|c|}
\hline \multicolumn{2}{|c|}{ Nutrition Facts } \\
\hline \multicolumn{2}{|l|}{ Calories 434} \\
\hline & \% Daily Value \\
\hline Total Fat $5 \mathrm{~g}$ & $7 \%$ \\
\hline Saturated Fat $2 \mathrm{~g}$ & $11 \%$ \\
\hline \multicolumn{2}{|l|}{ Trans Fat $\mathbf{0} \mathrm{g}$} \\
\hline Cholesterol $11 \mathrm{mg}$ & $4 \%$ \\
\hline Sodium $295 \mathrm{mg}$ & $12 \%$ \\
\hline Carbohydrate $84 \mathrm{~g}$ & $28 \%$ \\
\hline Dietary Fiber $6 \mathrm{~g}$ & $23 \%$ \\
\hline \multicolumn{2}{|l|}{ Sugars $64 \mathrm{~g}$} \\
\hline \multicolumn{2}{|l|}{ Protein $16 \mathrm{~g}$} \\
\hline Vitamin A & Vitamin C $27 \%$ \\
\hline Calcium & Iron \\
\hline
\end{tabular}




\section{DAY EIGHTEEN}

Nutrition Education: Iron- Not Just what you Pump at the Gym!

Iron helps carry oxygen throughout the body leaving you energized and ready to go! You can find iron in whole grains, green leafy vegetables, bread, spinach, turnip, broccoli, dry fruits, and meat products.

For information on iron, please visit:

http://www.eatright.org/Public/content.aspx?id=6798\&terms=iron

Recipe: Whole Wheat Blueberry Pancakes

Ingredients:

$1 / 2 c$ frozen blueberries

1 cup whole wheat pancake mix

1 cup skim milk

$1 \mathrm{egg}$

$1 \mathrm{~T}$ vegetable oil

4 T syrup

2 cups strawberries, quartered or your favorite fruit

Non-stick pan spray

Directions:

1. Combine pancake mix, skim milk, egg, and vegetable oil. Stir until mixed well.

2. Spray with non-stick pan spray and heat griddle on stove.

3. Add blueberries into pancake mix.

4. Distribute batter evenly to make four pancakes.

5. Enjoy with strawberries

Serves 2 . 


\section{Nutrition Facts}

Calories 328

\% Daily Value

otal Fat $6 \mathrm{~g} \quad 10 \%$

Saturated Fat $2 \mathrm{~g} \quad 11 \%$

Trans Fat $0 \mathrm{~g}$

Cholesterol $54 \mathrm{mg} \quad 18 \%$

Sodium $559 \mathrm{mg} \quad 23 \%$

Carbohydrate $64 \mathrm{~g} \quad 21 \%$

Dietary Fiber $7 \mathrm{~g} \quad 27 \%$

Sugars $29 \mathrm{~g}$

Protein $9 \mathrm{~g}$

\begin{tabular}{lll} 
Vitamin A & $5 \%$ & Vitamin C $151 \%$ \\
\hline
\end{tabular}

\begin{tabular}{llll} 
Calcium & $25 \%$ & Iron & $20 \%$ \\
\hline
\end{tabular}




\section{DAY NINETEEN}

Nutrition: Make it a MyPlate Breakfast!

Try the recipe below and add an $8 \mathrm{oz}$. glass of low-fat or non-fat milk, a fruit cup, and piece of whole wheat toast. This will offer a serving from every food group!

For more information on MyPlate, please visit www.choosemyplate.gov

Recipe: Vegetable Frittata

Ingredients:

$16 \mathrm{oz}$. egg beaters

$1 \mathrm{~T}$ olive oil

1 white onion, sliced thinly

1 small zucchini, sliced thinly

1 small yellow squash, sliced thinly

1 green bell pepper, sliced thinly

1 cup shredded cheese, low-fat

1 cup frozen cauliflower

Non-stick pan spray

Directions:

1. Preheat oven to $325 \mathrm{~F}$.

2. In a sauté pan, heat the olive oil over medium heat.

3. Sauté onions, zucchini, yellow squash, green bell pepper, and cauliflower for 5 minutes.

4. Spray an $8 \times 10$ baking dish with non-stick pan spray, then place the sautéed vegetables evenly on the bottom.

5. Carefully pour the egg beaters over the vegetables.

6. Top with cheese.

7. Bake for 25-30 minutes.

Serves 4. 


\begin{tabular}{|c|c|}
\hline Nutrition Fac & \\
\hline Calories 233 & \\
\hline & \% Daily Value \\
\hline Total Fat $13 \mathrm{~g}$ & $20 \%$ \\
\hline Saturated Fat $3 \mathrm{~g}$ & $15 \%$ \\
\hline Trans Fat $0 \mathrm{~g}$ & \\
\hline Cholesterol $0 \mathrm{mg}$ & $0 \%$ \\
\hline Sodium $225 \mathrm{mg}$ & $9 \%$ \\
\hline Carbohydrate $11 \mathrm{~g}$ & $4 \%$ \\
\hline Dietary Fiber $7 \mathrm{~g}$ & $27 \%$ \\
\hline Sugars $4 \mathrm{~g}$ & \\
\hline Protein $20 \mathrm{~g}$ & \\
\hline Vitamin A & Vitamin C $118 \%$ \\
\hline Calcium & Iron $\quad 20 \%$ \\
\hline
\end{tabular}




\section{DAY TWENTY}

Nutrition Education: Avocadoes are High in Heart-Healthy Unsaturated Fat!

Unsaturated fats help to reduce cholesterol and lower the risk of heart disease.

Excellent examples of foods high in unsaturated fats are: peanut butter, olives, nuts, avocado, vegetable oils, fish, and flaxseed.

To learn how to select, pit and peel an avocado, please watch this YouTube video: http://www.youtube.com/watch?v=bKVgqFEUnuU

Recipe: Breakfast Burritos with Orange Slices

Ingredients:

4 whole wheat tortillas

8 oz. egg beaters

4 oz. shredded low-fat cheddar cheese

4 slices turkey bacon

1 avocado

4 oranges

Directions:

1. In a sauté pan, cook turkey bacon slices to desired doneness.

2. After removing bacon from pan, cook egg beaters until done.

3. While the egg beaters are cooking, slice the avocado and oranges.

4. Assembly burrito by distributing egg beaters between four tortillas, top with avocado, one turkey bacon slice, and cheese.

5. Enjoy with your orange slices

Serves 4

\begin{tabular}{|c|c|}
\hline \multicolumn{2}{|c|}{ Nutrition Facts } \\
\hline \multicolumn{2}{|l|}{ Calories 351} \\
\hline & \% Daily Value \\
\hline Total Fat $15 \mathrm{~g}$ & $22 \%$ \\
\hline Saturated Fat $4 \mathrm{~g}$ & $19 \%$ \\
\hline Trans Fat $0 \mathrm{~g}$ & \\
\hline Cholesterol $22 \mathrm{mg}$ & $7 \%$ \\
\hline Sodium $650 \mathrm{mg}$ & $27 \%$ \\
\hline Carbohydrate $36 \mathrm{~g}$ & $12 \%$ \\
\hline Dietary Fiber $8 \mathrm{~g}$ & $33 \%$ \\
\hline Sugars $18 \mathrm{~g}$ & \\
\hline Protein $22 \mathrm{~g}$ & \\
\hline Vitamin A $\quad 15 \%$ & Vitamin C $144 \%$ \\
\hline Calcium & Iron $\quad 13 \%$ \\
\hline
\end{tabular}




\section{DAY TWENTY-ONE}

Nutrition Education: Breakfast on the Go!

Never sacrifice breakfast because you're running late or you have a jam-packed day. Keep easy, quick-to-grab foods in your dorm or apartment. Some examples of these can include: portable fruit like bananas, peaches, apples, or oranges, granola barsgo for protein/fiber bars, bagels, and peanut butter crackers.

To more tips on which granola bars to choose, please visit: https://www.urmc.rochester.edu/encyclopedia/content.aspx?ContentTypeID=1\&C ontentID $=1593$

Recipe: Toasted Peanut Butter and Banana Sandwich

Ingredients:

2 slices whole wheat bread

2 Tbsp peanut butter, creamy or chunky

1 cup banana slices

Directions:

1. Toast the bread slices to your desired doneness.

2. Spread the peanut butter on your toast and place the banana slices on top of the peanut butter.

3. Enjoy while walking to class!

Serves 1.

\begin{tabular}{|c|c|}
\hline \multicolumn{2}{|c|}{ Nutrition Facts } \\
\hline \multicolumn{2}{|c|}{ Calories 475} \\
\hline & \% Daily Value \\
\hline Total Fat $19 \mathrm{~g}$ & $28 \%$ \\
\hline Saturated Fat $3 \mathrm{~g}$ & $16 \%$ \\
\hline \multicolumn{2}{|l|}{ Trans Fat $0 \mathrm{~g}$} \\
\hline Cholesterol $0 \mathrm{mg}$ & $0 \%$ \\
\hline Sodium $298 \mathrm{mg}$ & $12 \%$ \\
\hline Carbohydrate $67 \mathrm{~g}$ & $22 \%$ \\
\hline Dietary Fiber $11 \mathrm{~g}$ & $44 \%$ \\
\hline \multicolumn{2}{|l|}{ Sugars $24 \mathrm{~g}$} \\
\hline \multicolumn{2}{|l|}{ Protein $17 \mathrm{~g}$} \\
\hline Vitamin A & Vitamin C $22 \%$ \\
\hline Calcium & Iron $\quad 14 \%$ \\
\hline
\end{tabular}




\section{Appendix B}

\section{Data collection instrument}

\section{REAP SURVEY PRE-TEST}

\begin{tabular}{|c|c|c|}
\hline a. Are you 18 years or older? & $\begin{array}{l}0 \\
0\end{array}$ & $\begin{array}{l}\text { Yes } \\
\text { No }\end{array}$ \\
\hline b. How old are you? & 0 & \\
\hline c. To which gender do you identify with? & $\begin{array}{l}0 \\
\mathrm{O}\end{array}$ & $\begin{array}{l}\text { Male } \\
\text { Female }\end{array}$ \\
\hline d. How would you identify your ethnicity? & $\begin{array}{l}0 \\
0 \\
0 \\
0 \\
0\end{array}$ & $\begin{array}{l}\text { Hispanic or } \\
\text { Latino } \\
\text { American Indian } \\
\text { or Alaska Native } \\
\text { Asian } \\
\text { African American } \\
\text { Native Hawaiian } \\
\text { or Other Pacific } \\
\text { Islander } \\
\text { White } \\
\end{array}$ \\
\hline e. Please indicate your current college grade level. & $\begin{array}{l}0 \\
0 \\
0 \\
0 \\
0\end{array}$ & $\begin{array}{l}\text { Freshman } \\
\text { Sophomore } \\
\text { Junior } \\
\text { Senior } \\
\text { Graduate }\end{array}$ \\
\hline f. Are you a full time student? & $\begin{array}{l}0 \\
0\end{array}$ & $\begin{array}{l}\text { Yes } \\
\text { No }\end{array}$ \\
\hline 1. How frequently do you skip breakfast during the week? & $\begin{array}{l}0 \\
0 \\
0\end{array}$ & $\begin{array}{l}\text { Usually/often } \\
\text { Sometimes } \\
\text { Never }\end{array}$ \\
\hline $\begin{array}{l}\text { How often do you eat meals from sit-down or take out } \\
\text { restaurants a week? }\end{array}$ & $\begin{array}{l}0 \\
0 \\
0\end{array}$ & $\begin{array}{l}\text { Usually/often } \\
\text { Sometimes } \\
\text { Never } \\
\end{array}$ \\
\hline $\begin{array}{l}\text { 3. How often do you eat more than } 3 \text { servings of refined grain } \\
\text { products a day? (Serving= } 1 \text { slice of white bread, } 1 / 2 \text { cup white } \\
\text { pasta, } 1 \text { cup white rice, } 1 \text { white tortilla, } 1 \text { dinner roll, } 3-4 \text { plain } \\
\text { crackers) }\end{array}$ & $\begin{array}{l}0 \\
0 \\
0\end{array}$ & $\begin{array}{l}\text { Usually/often } \\
\text { Sometimes } \\
\text { Never }\end{array}$ \\
\hline $\begin{array}{l}\text { 4. How often do you eat fewer than } 3 \text { servings of whole grain } \\
\text { products a day? (Serving=1 slice of } 100 \% \text { whole grain bread, } 1 \\
\text { cup whole grain cereal, high fiber cereals, oatmeal, } 3-4 \text { whole } \\
\text { grain crackers, } 1 / 2 \text { cup brown rice or whole wheat pasta) }\end{array}$ & $\begin{array}{l}0 \\
0 \\
0\end{array}$ & $\begin{array}{l}\text { Usually/often } \\
\text { Sometimes } \\
\text { Never }\end{array}$ \\
\hline $\begin{array}{l}\text { 5. How often do you eat fewer than } 2-3 \text { servings of fruit a day? } \\
\text { (Serving }=1 / 2 \text { cup or } 1 \text { medium fruit or } 4 \text { oz. } 100 \% \text { fruit juice) }\end{array}$ & $\begin{array}{l}0 \\
0 \\
0\end{array}$ & $\begin{array}{l}\text { Usually/often } \\
\text { Sometimes } \\
\text { Never }\end{array}$ \\
\hline $\begin{array}{l}\text { 6. How often do you eat fewer than 3-4 servings of red fruit a } \\
\text { week? (Red fruit= red apples, cranberries, pomegranates, } \\
\text { raspberries, strawberries, watermelon) }\end{array}$ & $\begin{array}{l}0 \\
0 \\
0\end{array}$ & $\begin{array}{l}\text { Usually/often } \\
\text { Sometimes } \\
\text { Never }\end{array}$ \\
\hline $\begin{array}{l}\text { 7. How often do you eat fewer than 3-4 servings of blue/purple } \\
\text { fruit a week? (Blue/purple fruit= raisins, blueberries, plums, } \\
\text { purple grapes) }\end{array}$ & $\begin{array}{l}0 \\
0 \\
0\end{array}$ & $\begin{array}{l}\text { Usually/often } \\
\text { Sometimes } \\
\text { Never }\end{array}$ \\
\hline
\end{tabular}




\begin{tabular}{|c|c|c|}
\hline $\begin{array}{l}\text { 8. How often do you eat fewer than 3-4 servings of white fruit a } \\
\text { week? (White fruit= bananas, white nectarines, white peaches) }\end{array}$ & $\begin{array}{l} \\
\circ \\
\circ \\
0\end{array}$ & $\begin{array}{l}\text { Usually/often } \\
\text { Sometimes } \\
\text { Never }\end{array}$ \\
\hline $\begin{array}{l}\text { 9. How often do you eat fewer than } 3-4 \text { servings of green fruit a } \\
\text { week? (Green fruit= green apples, green grapes, kiwi, } \\
\text { honeydew melon) }\end{array}$ & $\begin{array}{l}0 \\
0 \\
0\end{array}$ & $\begin{array}{l}\text { Usually/often } \\
\text { Sometimes } \\
\text { Never }\end{array}$ \\
\hline $\begin{array}{l}\text { 10. How often do you eat fewer than } 3-4 \text { servings of } \\
\text { yellow/orange fruit a week? (Yellow/orange fruit= yellow } \\
\text { apples, apricots, cantaloupe, oranges, peaches, nectarines, } \\
\text { mangoes, pineapple) }\end{array}$ & $\begin{array}{l}0 \\
0 \\
0\end{array}$ & $\begin{array}{l}\text { Usually/often } \\
\text { Sometimes } \\
\text { Never }\end{array}$ \\
\hline $\begin{array}{l}\text { 11. How often do you eat fewer than 3-4 servings of } \\
\text { vegetables/potatoes a day? (Serving }=1 / 2 \text { cup } \\
\text { vegetable/potatoes, or } 1 \text { cup leafy raw vegetables) }\end{array}$ & $\begin{array}{ll}\circ \\
\circ \\
\circ\end{array}$ & $\begin{array}{l}\text { Usually/often } \\
\text { Sometimes } \\
\text { Never }\end{array}$ \\
\hline $\begin{array}{l}\text { 12. How often you eat fewer than } 4-5 \text { red vegetables a week? (Red } \\
\text { vegetables= tomatoes, radishes, radicchio, red peppers, red } \\
\text { onions) }\end{array}$ & $\begin{array}{l}\circ \\
\circ \\
\circ \\
\end{array}$ & $\begin{array}{l}\text { Usually/often } \\
\text { Sometimes } \\
\text { Never }\end{array}$ \\
\hline $\begin{array}{l}\text { 13. How often do you eat fewer than } 4-5 \text { blue/purple vegetables a } \\
\text { week? (Blue/purple vegetables= eggplant, purple cabbage, } \\
\text { purple pepper, purple potato) }\end{array}$ & $\begin{array}{l}\circ \\
\circ \\
\circ \\
\circ\end{array}$ & $\begin{array}{l}\text { Usually/often } \\
\text { Sometimes } \\
\text { Never }\end{array}$ \\
\hline $\begin{array}{l}\text { 14. How often do you eat fewer than } 4-5 \text { white vegetables a week? } \\
\text { (White vegetables= garlic, cauliflower, mushrooms, onions, } \\
\text { potatoes) }\end{array}$ & $\begin{array}{l}\circ \\
\circ \\
\circ \\
\circ\end{array}$ & $\begin{array}{l}\text { Usually/often } \\
\text { Sometimes } \\
\text { Never }\end{array}$ \\
\hline $\begin{array}{l}\text { 15. How often do you eat fewer than 4-5 green vegetables a week? } \\
\text { (Green vegetables= avocado, broccoli, spinach, okra, artichoke, } \\
\text { zucchini, lettuce, celery, asparagus) }\end{array}$ & $\begin{array}{l}\mathrm{O} \\
\circ \\
\circ \\
\circ\end{array}$ & $\begin{array}{l}\text { Usually/often } \\
\text { Sometimes } \\
\text { Never }\end{array}$ \\
\hline $\begin{array}{l}\text { 16. How often do you eat fewer than } 4-5 \text { yellow/orange vegetables } \\
\text { a week? (Yellow/orange vegetables= yellow peppers, pumpkin, } \\
\text { sweet corn, yellow tomatoes, sweet potatoes) }\end{array}$ & $\begin{array}{ll}\circ \\
\circ \\
\circ\end{array}$ & $\begin{array}{l}\text { Usually/often } \\
\text { Sometimes } \\
\text { Never }\end{array}$ \\
\hline $\begin{array}{l}\text { 17. How often do you eat or drink fewer than } 2-3 \text { servings of milk, } \\
\text { yogurt, or cheese a day? (Serving = } 1 \text { cup milk or yogurt; } 1 \frac{1}{2}-2 \\
\text { ounces cheese) }\end{array}$ & $\begin{array}{l}\circ \\
\circ \\
\circ\end{array}$ & $\begin{array}{l}\text { Usually/often } \\
\text { Sometimes } \\
\text { Never }\end{array}$ \\
\hline $\begin{array}{l}\text { 18. How often do you use } 2 \% \text { (reduced fat) or whole milk instead } \\
\text { of skim (non-fat) or } 1 \% \text { (low-fat) milk? }\end{array}$ & $\begin{array}{l}0 \\
0 \\
0\end{array}$ & $\begin{array}{l}\text { Usually/often } \\
\text { Sometimes } \\
\text { Never }\end{array}$ \\
\hline $\begin{array}{l}\text { 19. How often do you use regular cheese (like American, cheddar, } \\
\text { Swiss, Monterey jack) instead of low fat or part skim cheeses as } \\
\text { a snack, on sandwiches, pizza, etc.? }\end{array}$ & $\begin{array}{l}\circ \\
\circ \\
\circ \\
\end{array}$ & $\begin{array}{l}\text { Usually/often } \\
\text { Sometimes } \\
\text { Never }\end{array}$ \\
\hline $\begin{array}{l}\text { 20. How often do you eat beef, pork, or dark meat chicken more } \\
\text { than } 2 \text { times a week? }\end{array}$ & $\begin{array}{l}\circ \\
\circ \\
\circ \\
\circ\end{array}$ & $\begin{array}{l}\text { Usually/often } \\
\text { Sometimes } \\
\text { Never }\end{array}$ \\
\hline $\begin{array}{l}\text { 21. How often do you eat more than } 6 \text { ounces of meat, chicken, } \\
\text { turkey or fish per day? (Note: } 3 \text { ounces of meat or chicken is the } \\
\text { size of a deck of cards or ONE of the following: } 1 \text { regular } \\
\text { hamburger, } 1 \text { chicken breast or leg (thigh \& drumstick), or } 1 \\
\text { pork chop.) }\end{array}$ & $\begin{array}{l}0 \\
0 \\
0\end{array}$ & $\begin{array}{l}\text { Usually/often } \\
\text { Sometimes } \\
\text { Never }\end{array}$ \\
\hline $\begin{array}{l}\text { 22. How often do you choose higher fat red meats like prime rib, T- } \\
\text { bone steak, hamburger, ribs, etc. instead of lean red meats like } \\
\text { top round, top sirloin steak, brisket, top loin, round steak, flank } \\
\text { steak? }\end{array}$ & $\begin{array}{l}0 \\
0 \\
0\end{array}$ & $\begin{array}{l}\text { Usually/often } \\
\text { Sometimes } \\
\text { Never }\end{array}$ \\
\hline $\begin{array}{l}\text { 23. How often do you eat the skin on chicken and turkey or the fat } \\
\text { on meat? }\end{array}$ & $\begin{array}{l}\circ \\
\circ \\
\circ\end{array}$ & $\begin{array}{l}\text { Usually/often } \\
\text { Sometimes } \\
\text { Never }\end{array}$ \\
\hline
\end{tabular}




\begin{tabular}{|c|c|c|}
\hline $\begin{array}{l}\text { 24. How often do you use regular processed meats (like bologna, } \\
\text { salami, corned beef, hotdogs, sausage or bacon) instead of low } \\
\text { fat processed meats (like roast beef, turkey, lean ham; low-fat } \\
\text { cold cuts/hotdogs)? }\end{array}$ & $\begin{array}{l}\circ \\
\circ \\
\circ\end{array}$ & $\begin{array}{l}\text { Usually/often } \\
\text { Sometimes } \\
\text { Never }\end{array}$ \\
\hline $\begin{array}{l}\text { 25. How often do you eat fried foods such as fried chicken, fried } \\
\text { fish, or French fries? }\end{array}$ & 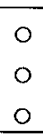 & $\begin{array}{l}\text { Usually/often } \\
\text { Sometimes } \\
\text { Never }\end{array}$ \\
\hline $\begin{array}{l}\text { 26. How often do you eat regular potato chips, nacho chips, corn } \\
\text { chips, crackers, regular popcorn, or nuts instead of pretzels, } \\
\text { low-fat chips or low-fat crackers, air-popped popcorn? }\end{array}$ & $\begin{array}{l}0 \\
\\
\circ \\
0\end{array}$ & $\begin{array}{l}\text { Usually/often } \\
\text { Sometimes } \\
\text { Never }\end{array}$ \\
\hline $\begin{array}{l}\text { 27. How often do you use regular salad dressing \& mayonnaise } \\
\text { instead of low-fat or fat-free salad dressing and mayonnaise? }\end{array}$ & $\begin{array}{l}0 \\
\circ \\
\circ \\
\circ\end{array}$ & $\begin{array}{l}\text { Usually/often } \\
\text { Sometimes } \\
\text { Never }\end{array}$ \\
\hline $\begin{array}{l}\text { 28. How often do you add butter, margarine or oil to bread, } \\
\text { potatoes, rice or vegetables at the table? }\end{array}$ & $\begin{array}{l}\circ \\
\circ \\
\circ \\
\circ\end{array}$ & $\begin{array}{l}\text { Usually/often } \\
\text { Sometimes } \\
\text { Never }\end{array}$ \\
\hline $\begin{array}{l}\text { 29. How often do you cook with oil, butter or margarine instead of } \\
\text { using non-stick sprays like Pam or cooking without fat? }\end{array}$ & $\begin{array}{l}0 \\
\circ \\
\circ\end{array}$ & $\begin{array}{l}\text { Usually/often } \\
\text { Sometimes } \\
\text { Never }\end{array}$ \\
\hline $\begin{array}{l}\text { 30. How often do you eat regular sweets like cake, cookies, pastries, } \\
\text { donuts, muffins, and chocolate instead of low fat or fat-free } \\
\text { sweets? }\end{array}$ & $\begin{array}{l}0 \\
\circ \\
\circ \\
\circ\end{array}$ & $\begin{array}{l}\text { Usually/often } \\
\text { Sometimes } \\
\text { Never }\end{array}$ \\
\hline $\begin{array}{l}\text { 31. How often do you eat regular ice cream instead of sherbet, } \\
\text { sorbet, low fat or fat-free ice cream, frozen yogurt, etc.? }\end{array}$ & $\begin{array}{l}\circ \\
\circ \\
\circ \\
\circ\end{array}$ & $\begin{array}{l}\text { Usually/often } \\
\text { Sometimes } \\
\text { Never }\end{array}$ \\
\hline $\begin{array}{l}\text { 32. Do you eat sweets like cake, cookies, pastries, donuts, muffins, } \\
\text { chocolate and candies more than } 2 \text { times per } \\
\text { day? }\end{array}$ & $\begin{array}{l}\circ \\
\circ \\
\circ \\
\circ\end{array}$ & $\begin{array}{l}\text { Usually/often } \\
\text { Sometimes } \\
\text { Never }\end{array}$ \\
\hline $\begin{array}{l}\text { 33. Do you drink } 16 \text { ounces or more of non-diet soda, fruit } \\
\text { drink/punch or Kool-Aid a day? (Note: } 1 \text { can of soda }=12 \\
\text { ounces) }\end{array}$ & $\begin{array}{l}\circ \\
\circ \\
\circ \\
\circ\end{array}$ & $\begin{array}{l}\text { Usually/often } \\
\text { Sometimes } \\
\text { Never }\end{array}$ \\
\hline $\begin{array}{l}\text { 34. Do you eat high sodium processed foods like canned soup or } \\
\text { pasta, frozen/packaged meals (TV dinners, etc.), chips? }\end{array}$ & $\begin{array}{l}\circ \\
\circ \\
\circ \\
\circ\end{array}$ & $\begin{array}{l}\text { Usually/often } \\
\text { Sometimes } \\
\text { Never }\end{array}$ \\
\hline $\begin{array}{l}\text { 35. How often do you add salt to foods during cooking or at the } \\
\text { table? }\end{array}$ & $\begin{array}{l}\circ \\
\circ \\
\circ\end{array}$ & $\begin{array}{l}\text { Usually/often } \\
\text { Sometimes } \\
\text { Never }\end{array}$ \\
\hline $\begin{array}{l}\text { 36. How often do you drink more than 1-2 alcoholic drinks a day? } \\
\text { (One drink = } 12 \text { oz. beer, } 5 \mathrm{oz} \text {. Wine, one shot of hard liquor or } \\
\text { mixed drink with } 1 \text { shot) }\end{array}$ & $\begin{array}{l}\circ \\
\circ \\
\circ\end{array}$ & $\begin{array}{l}\text { Usually/often } \\
\text { Sometimes } \\
\text { Never }\end{array}$ \\
\hline $\begin{array}{l}\text { 37. How often do you do fewer than } 30 \text { total minutes of physical } \\
\text { activity } 3 \text { days a week or more? (Examples: walking briskly, } \\
\text { gardening, golf, jogging, swimming, biking, dancing, etc.) }\end{array}$ & $\begin{array}{l}0 \\
\circ \\
\circ\end{array}$ & $\begin{array}{l}\text { Usually/often } \\
\text { Sometimes } \\
\text { Never }\end{array}$ \\
\hline $\begin{array}{l}\text { 38. How often do you watch more than } 2 \text { hours of television or } \\
\text { videos a day? }\end{array}$ & $\begin{array}{l}0 \\
\circ \\
0\end{array}$ & $\begin{array}{l}\text { Usually/often } \\
\text { Sometimes } \\
\text { Never }\end{array}$ \\
\hline 39. Do you usually shop and prepare your own food? & o & $\begin{array}{l}\text { Yes } \\
\text { No }\end{array}$ \\
\hline 40. Do you ever have trouble being able to shop or cook? & & $\begin{array}{l}\text { Yes } \\
\text { No }\end{array}$ \\
\hline $\begin{array}{l}\text { 41. Do you follow a special diet, eat or limit certain foods for health } \\
\text { or other reasons? }\end{array}$ & & $\begin{array}{l}\text { Yes } \\
\text { No }\end{array}$ \\
\hline
\end{tabular}


42. On a scale from 1-5, 1 being not at all and 5 being very willing, how willing are you to make changes to your lifestyle habits and eating habits.

$\begin{array}{cc}\circ & 1 \\ \circ & 2 \\ \circ & 3 \\ \circ & 4 \\ \circ & 5\end{array}$




\section{Appendix C}

\section{Data collection instrument}

\section{REAP SURVEY POST-TEST}

\begin{tabular}{|c|c|c|}
\hline 1. How frequently do you skip breakfast during the week? & $\begin{array}{l}0 \\
\circ \\
\circ \\
\circ\end{array}$ & $\begin{array}{l}\text { Usually/often } \\
\text { Sometimes } \\
\text { Never }\end{array}$ \\
\hline $\begin{array}{l}\text { How often do you eat } 4 \text { or more meals from sit-down or take } \\
\text { out restaurants a week? }\end{array}$ & $\begin{array}{l}\circ \\
\circ \\
\circ \\
\circ\end{array}$ & $\begin{array}{l}\text { Usually/often } \\
\text { Sometimes } \\
\text { Never }\end{array}$ \\
\hline $\begin{array}{l}\text { 3. How often do you eat more than } 3 \text { servings of refined grain } \\
\text { products a day? (Serving= } 1 \text { slice of white bread, } 1 / 2 \text { cup white } \\
\text { pasta, } 1 \text { cup white rice, } 1 \text { white tortilla, } 1 \text { dinner roll, 3-4 plain } \\
\text { crackers) }\end{array}$ & $\begin{array}{l}0 \\
\circ \\
0\end{array}$ & $\begin{array}{l}\text { Usually/often } \\
\text { Sometimes } \\
\text { Never }\end{array}$ \\
\hline $\begin{array}{l}\text { 4. How often do you eat fewer than } 3 \text { servings of grain products a } \\
\text { day? (Serving= } 1 \text { slice of } 100 \% \text { whole grain bread, } 1 \text { cup whole } \\
\text { grain cereal, high fiber cereals, oatmeal, } 3-4 \text { whole grain } \\
\text { crackers, } 1 / 2 \text { cup brown rice or whole wheat pasta) }\end{array}$ & $\begin{array}{l} \\
0 \\
0\end{array}$ & $\begin{array}{l}\text { Usually/often } \\
\text { Sometimes } \\
\text { Never }\end{array}$ \\
\hline $\begin{array}{l}\text { How often do you eat fewer than } 2-3 \text { servings of fruit a day? } \\
\text { (Serving= } 1 / 2 \text { cup or } 1 \text { medium fruit or } 4 \text { oz. } 100 \% \text { fruit juice) }\end{array}$ & $\begin{array}{l}\circ \\
\circ \\
\circ \\
\circ\end{array}$ & $\begin{array}{l}\text { Usually/often } \\
\text { Sometimes } \\
\text { Never }\end{array}$ \\
\hline $\begin{array}{l}\text { 6. How often do you eat fewer than 3-4 servings of red fruit a } \\
\text { week? (Red fruit= red apples, cranberries, pomegranates, } \\
\text { raspberries, strawberries, watermelon) }\end{array}$ & $\begin{array}{l}0 \\
\circ \\
\circ \\
0\end{array}$ & $\begin{array}{l}\text { Usually/often } \\
\text { Sometimes } \\
\text { Never }\end{array}$ \\
\hline $\begin{array}{l}\text { 7. How often do you eat fewer than } 3-4 \text { servings of blue/purple } \\
\text { fruit a week? (Blue/purple fruit= raisins, blueberries, plums, } \\
\text { purple grapes) }\end{array}$ & $\begin{array}{l}0 \\
\circ \\
\circ\end{array}$ & $\begin{array}{l}\text { Usually/often } \\
\text { Sometimes } \\
\text { Never }\end{array}$ \\
\hline $\begin{array}{l}\text { 8. How often do you eat fewer than } 3-4 \text { servings of white fruit a } \\
\text { week? (White fruit= bananas, white nectarines, white peaches) }\end{array}$ & $\begin{array}{l}\circ \\
\circ \\
\circ \\
\circ\end{array}$ & $\begin{array}{l}\text { Usually/often } \\
\text { Sometimes } \\
\text { Never }\end{array}$ \\
\hline $\begin{array}{l}\text { 9. How often do you eat fewer than } 3-4 \text { servings of green fruit a } \\
\text { week? (Green fruit= green apples, green grapes, kiwi, } \\
\text { honeydew melon) }\end{array}$ & $\begin{array}{l}\circ \\
\circ \\
\circ \\
\circ\end{array}$ & $\begin{array}{l}\text { Usually/often } \\
\text { Sometimes } \\
\text { Never }\end{array}$ \\
\hline $\begin{array}{l}\text { 10. How often do you eat fewer than 3-4 servings of } \\
\text { yellow/orange fruit a week? (Yellow/orange fruit= yellow } \\
\text { apples, apricots, cantaloupe, oranges, peaches, nectarines, } \\
\text { mangoes, pineapple) }\end{array}$ & $\begin{array}{l}\circ \\
\circ \\
\circ \\
\circ\end{array}$ & $\begin{array}{l}\text { Usually/often } \\
\text { Sometimes } \\
\text { Never }\end{array}$ \\
\hline $\begin{array}{l}\text { 11. How often do you eat fewer than } 3-4 \text { servings of } \\
\text { vegetables/potatoes a day? (Serving= } 1 / 2 \text { cup } \\
\text { vegetable/potatoes, or } 1 \text { cup leafy raw vegetables) }\end{array}$ & $\begin{array}{l}\circ \\
\circ \\
\circ \\
\circ\end{array}$ & $\begin{array}{l}\text { Usually/often } \\
\text { Sometimes } \\
\text { Never }\end{array}$ \\
\hline $\begin{array}{l}\text { 12. How often you eat fewer than } 4-5 \text { red vegetables a week? (Red } \\
\text { vegetables= tomatoes, radishes, radicchio, red peppers, red } \\
\text { onions) }\end{array}$ & $\begin{array}{l}\circ \\
\circ \\
\circ\end{array}$ & $\begin{array}{l}\text { Usually/often } \\
\text { Sometimes } \\
\text { Never }\end{array}$ \\
\hline $\begin{array}{l}\text { 13. How often do you eat fewer than } 4-5 \text { blue/purple vegetables a } \\
\text { week? (Blue/purple vegetables= eggplant, purple cabbage, } \\
\text { purple pepper, purple potato) }\end{array}$ & $\begin{array}{l}\circ \\
\circ \\
\circ\end{array}$ & $\begin{array}{l}\text { Usually/often } \\
\text { Sometimes } \\
\text { Never }\end{array}$ \\
\hline $\begin{array}{l}\text { 14. How often do you eat fewer than } 4-5 \text { white vegetables a week? } \\
\text { (White vegetables= garlic, cauliflower, mushrooms, onions, } \\
\text { potatoes) }\end{array}$ & $\begin{array}{l}\circ \\
\circ \\
\circ \\
\circ\end{array}$ & $\begin{array}{l}\text { Usually/often } \\
\text { Sometimes } \\
\text { Never }\end{array}$ \\
\hline
\end{tabular}




\begin{tabular}{|c|c|c|}
\hline $\begin{array}{l}\text { 15. How often do you eat fewer than } 4-5 \text { green vegetables a week? } \\
\text { (Green vegetables= avocado, broccoli, spinach, okra, artichoke, } \\
\text { zucchini, lettuce, celery, asparagus) }\end{array}$ & $\begin{array}{l}0 \\
\circ \\
0\end{array}$ & $\begin{array}{l}\text { Usually/often } \\
\text { Sometimes } \\
\text { Never }\end{array}$ \\
\hline $\begin{array}{l}\text { 16. How often do you eat fewer than 4-5 yellow/orange vegetables } \\
\text { a week? (Yellow/orange vegetables= yellow peppers, pumpkin, } \\
\text { sweet corn, yellow tomatoes, sweet potatoes) }\end{array}$ & $\begin{array}{l}0 \\
\circ \\
0\end{array}$ & $\begin{array}{l}\text { Usually/often } \\
\text { Sometimes } \\
\text { Never }\end{array}$ \\
\hline $\begin{array}{l}\text { 17. How often do you eat or drink fewer than } 2-3 \text { servings of milk, } \\
\text { yogurt, or cheese a day? (Serving = } 1 \text { cup milk or yogurt; } 1 \frac{112-2}{2} \text { ounces cheese) }\end{array}$ & $\begin{array}{l}\circ \\
\circ \\
\circ \\
\circ\end{array}$ & $\begin{array}{l}\text { Usually/often } \\
\text { Sometimes } \\
\text { Never }\end{array}$ \\
\hline $\begin{array}{l}\text { 18. How often do you use } 2 \% \text { (reduced fat) or whole milk instead } \\
\text { of skim (non-fat) or } 1 \% \text { (low-fat) milk? }\end{array}$ & $\begin{array}{l}0 \\
0 \\
0\end{array}$ & $\begin{array}{l}\text { Usually/often } \\
\text { Sometimes } \\
\text { Never }\end{array}$ \\
\hline $\begin{array}{l}\text { 19. How often do you use regular cheese (like American, cheddar, } \\
\text { Swiss, Monterey jack) instead of low fat or part skim cheeses as } \\
\text { a snack, on sandwiches, pizza, etc.? }\end{array}$ & $\begin{array}{l}\circ \\
\circ \\
\circ\end{array}$ & $\begin{array}{l}\text { Usually/often } \\
\text { Sometimes } \\
\text { Never }\end{array}$ \\
\hline $\begin{array}{l}\text { 20. How often do you eat beef, pork, or dark meat chicken more } \\
\text { than } 2 \text { times a week? }\end{array}$ & $\begin{array}{ll} \\
\circ \\
\circ \\
\circ\end{array}$ & $\begin{array}{l}\text { Usually/often } \\
\text { Sometimes } \\
\text { Never }\end{array}$ \\
\hline $\begin{array}{l}\text { 21. How often do you eat more than } 6 \text { ounces of meat, chicken, } \\
\text { turkey or fish per day? (Note: } 3 \text { ounces of meat or chicken is the } \\
\text { size of a deck of cards or ONE of the following: } 1 \text { regular } \\
\text { hamburger, } 1 \text { chicken breast or leg (thigh \& drumstick), or } 1 \\
\text { pork chop.) }\end{array}$ & $\begin{array}{l}\circ \\
\circ \\
\circ\end{array}$ & $\begin{array}{l}\text { Usually/often } \\
\text { Sometimes } \\
\text { Never }\end{array}$ \\
\hline $\begin{array}{l}\text { 22. How often do you choose higher fat red meats like prime rib, T- } \\
\text { bone steak, hamburger, ribs, etc. instead of lean red meats like } \\
\text { top round, top sirloin steak, brisket, top loin, round steak, flank } \\
\text { steak? }\end{array}$ & $\begin{array}{l} \\
\circ \\
\circ\end{array}$ & $\begin{array}{l}\text { Usually/often } \\
\text { Sometimes } \\
\text { Never }\end{array}$ \\
\hline $\begin{array}{l}\text { 23. How often do you eat the skin on chicken and turkey or the fat } \\
\text { on meat? }\end{array}$ & $\begin{array}{l}\circ \\
\circ \\
\circ \\
\circ\end{array}$ & $\begin{array}{l}\text { Usually/often } \\
\text { Sometimes } \\
\text { Never }\end{array}$ \\
\hline $\begin{array}{l}\text { 24. How often do you use regular processed meats (like bologna, } \\
\text { salami, corned beef, hotdogs, sausage or bacon) instead of low } \\
\text { fat processed meats (like roast beef, turkey, lean ham; low-fat } \\
\text { cold cuts/hotdogs)? }\end{array}$ & $\begin{array}{l}\circ \\
\circ \\
\circ\end{array}$ & $\begin{array}{l}\text { Usually/often } \\
\text { Sometimes } \\
\text { Never }\end{array}$ \\
\hline $\begin{array}{l}\text { 25. How often do you eat fried foods such as fried chicken, fried } \\
\text { fish, or French fries? }\end{array}$ & $\begin{array}{ll}\circ \\
\circ \\
\circ\end{array}$ & $\begin{array}{l}\text { Usually/often } \\
\text { Sometimes } \\
\text { Never }\end{array}$ \\
\hline $\begin{array}{l}\text { 26. How often do you eat regular potato chips, nacho chips, corn } \\
\text { chips, crackers, regular popcorn, or nuts instead of pretzels, } \\
\text { low-fat chips or low-fat crackers, air-popped popcorn? }\end{array}$ & $\begin{array}{l}\circ \\
\circ \\
\circ \\
\circ\end{array}$ & $\begin{array}{l}\text { Usually/often } \\
\text { Sometimes } \\
\text { Never }\end{array}$ \\
\hline $\begin{array}{l}\text { 27. How often do you use regular salad dressing \& mayonnaise } \\
\text { instead of low-fat or fat-free salad dressing and mayonnaise? }\end{array}$ & $\begin{array}{l}\circ \\
\circ \\
\circ \\
\circ\end{array}$ & $\begin{array}{l}\text { Usually/often } \\
\text { Sometimes } \\
\text { Never }\end{array}$ \\
\hline $\begin{array}{l}\text { 28. How often do you add butter, margarine or oil to bread, } \\
\text { potatoes, rice or vegetables at the table? }\end{array}$ & $\begin{array}{l}\circ \\
\circ \\
\circ \\
\circ\end{array}$ & $\begin{array}{l}\text { Usually/often } \\
\text { Sometimes } \\
\text { Never }\end{array}$ \\
\hline $\begin{array}{l}\text { 29. How often do you cook with oil, butter or margarine instead of } \\
\text { using non-stick sprays like Pam or cooking without fat? }\end{array}$ & $\begin{array}{l}0 \\
0 \\
0\end{array}$ & $\begin{array}{l}\text { Usually/often } \\
\text { Sometimes } \\
\text { Never }\end{array}$ \\
\hline $\begin{array}{l}\text { 30. How often do you eat regular sweets like cake, cookies, pastries, } \\
\text { donuts, muffins, and chocolate instead of low fat or fat-free } \\
\text { sweets? }\end{array}$ & $\begin{array}{l}0 \\
0 \\
0\end{array}$ & $\begin{array}{l}\text { Usually/often } \\
\text { Sometimes } \\
\text { Never }\end{array}$ \\
\hline
\end{tabular}




\begin{tabular}{|c|c|c|}
\hline $\begin{array}{l}\text { 31. How often do you eat regular ice cream instead of sherbet, } \\
\text { sorbet, low fat or fat-free ice cream, frozen yogurt, etc.? }\end{array}$ & $\begin{array}{l}\circ \\
\circ \\
\circ\end{array}$ & $\begin{array}{l}\text { Usually/often } \\
\text { Sometimes } \\
\text { Never }\end{array}$ \\
\hline $\begin{array}{l}\text { 32. Do you eat sweets like cake, cookies, pastries, donuts, muffins, } \\
\text { chocolate and candies more than } 2 \text { times per } \\
\text { day? }\end{array}$ & $\begin{array}{l}0 \\
0 \\
0\end{array}$ & $\begin{array}{l}\text { Usually/often } \\
\text { Sometimes } \\
\text { Never }\end{array}$ \\
\hline $\begin{array}{l}\text { 33. Do you drink } 16 \text { ounces or more of non-diet soda, fruit } \\
\text { drink/punch or Kool-Aid a day? (Note: } 1 \text { can of soda }=12 \\
\text { ounces) }\end{array}$ & $\begin{array}{l}\circ \\
\circ \\
\circ\end{array}$ & $\begin{array}{l}\text { Usually/often } \\
\text { Sometimes } \\
\text { Never }\end{array}$ \\
\hline $\begin{array}{l}\text { 34. Do you eat high sodium processed foods like canned soup or } \\
\text { pasta, frozen/packaged meals (TV dinners, etc.), chips? }\end{array}$ & $\begin{array}{l} \\
\\
\circ \\
\circ\end{array}$ & $\begin{array}{l}\text { Usually/often } \\
\text { Sometimes } \\
\text { Never }\end{array}$ \\
\hline $\begin{array}{l}\text { 35. How often do you add salt to foods during cooking or at the } \\
\text { table? }\end{array}$ & $\begin{array}{l}\circ \\
\circ \\
\circ\end{array}$ & $\begin{array}{l}\text { Usually/often } \\
\text { Sometimes } \\
\text { Never }\end{array}$ \\
\hline $\begin{array}{l}\text { 36. How often do you drink more than } 1-2 \text { alcoholic drinks a day? } \\
\text { (One drink = } 12 \text { oz. beer, } 5 \text { oz. Wine, one shot of hard liquor or } \\
\text { mixed drink with } 1 \text { shot) }\end{array}$ & $\begin{array}{l}0 \\
\circ \\
\circ \\
\circ\end{array}$ & $\begin{array}{l}\text { Usually/often } \\
\text { Sometimes } \\
\text { Never }\end{array}$ \\
\hline $\begin{array}{l}\text { 37. How often do you do fewer than } 30 \text { total minutes of physical } \\
\text { activity } 3 \text { days a week or more? (Examples: walking briskly, } \\
\text { gardening, golf, jogging, swimming, biking, dancing, etc.) }\end{array}$ & $\begin{array}{l}\circ \\
\circ \\
\circ \\
0\end{array}$ & $\begin{array}{l}\text { Usually/often } \\
\text { Sometimes } \\
\text { Never }\end{array}$ \\
\hline $\begin{array}{l}\text { 38. How often do you watch more than } 2 \text { hours of television or } \\
\text { videos a day? }\end{array}$ & $\begin{array}{l}0 \\
0 \\
0 \\
\end{array}$ & $\begin{array}{l}\text { Usually/often } \\
\text { Sometimes } \\
\text { Never }\end{array}$ \\
\hline 39. Do you usually shop and prepare your own food? & $\begin{array}{lll}\circ & 0 \\
\circ & 0 & 0 \\
\end{array}$ & $\begin{array}{l}\text { Yes } \\
\text { No }\end{array}$ \\
\hline 40. Do you ever have trouble being able to shop or cook? & $\begin{array}{lll}0 \\
\circ\end{array}$ & $\begin{array}{l}\text { Yes } \\
\text { No }\end{array}$ \\
\hline $\begin{array}{l}\text { 41. Do you follow a special diet, eat or limit certain foods for health } \\
\text { or other reasons? }\end{array}$ & $\begin{array}{ll}0 \\
\circ\end{array}$ & $\begin{array}{l}\text { Yes } \\
\text { No }\end{array}$ \\
\hline $\begin{array}{l}\text { 42. On a scale from } 1-5,1 \text { being not at all and } 5 \text { being very willing, } \\
\text { how willing are you to make changes to your lifestyle habits } \\
\text { and eating habits. }\end{array}$ & $\begin{array}{l}0 \\
0 \\
0 \\
0 \\
0\end{array}$ & $\begin{array}{l}1 \\
2 \\
3 \\
4 \\
5\end{array}$ \\
\hline $\begin{array}{l}\text { 43. How frequently did you check the Facebook group, Don't Waist } \\
\text { Your College Experience? }\end{array}$ & $\begin{array}{l}0 \\
0 \\
0 \\
0 \\
0 \\
0\end{array}$ & $\begin{array}{l}\text { Daily } \\
4-5 x / \text { week } \\
\text { 2-3x/week } \\
\text { 1x/week } \\
\text { Less than } \\
\text { 1x/week } \\
\text { Never } \\
\end{array}$ \\
\hline $\begin{array}{l}\text { 44. On a scale from } 1 \text { to } 5,1 \text { being not at all and } 5 \text { being very } \\
\text { satisfied, how satisfied were you with your experience with the } \\
\text { Facebook group, Don't Waist Your College Experience? }\end{array}$ & $\begin{array}{l}0 \\
0 \\
0 \\
0 \\
0\end{array}$ & $\begin{array}{l}1 \\
2 \\
3 \\
4 \\
5 \\
\end{array}$ \\
\hline $\begin{array}{l}\text { 45. How useful did you find the information posted on the } \\
\text { Facebook group, Don't Waist Your College Experience? }\end{array}$ & $\begin{array}{l}0 \\
0 \\
0\end{array}$ & $\begin{array}{l}\text { Very useful } \\
\text { Moderately } \\
\text { useful } \\
\text { Not useful }\end{array}$ \\
\hline
\end{tabular}


46. On a scale from 1 to 5,1 being not at all and 5 being very willing, how willing are you to share this information with others?

$\begin{array}{ll}\circ & 1 \\ \circ & 2 \\ \circ & 3 \\ \circ & 4 \\ \circ & 5\end{array}$

